\title{
Production and characterization of bio-oil and biochar from the pyrolysis of residual bacterial biomass from a polyhydroxyalkanoate production process
}

\author{
Liqing Wei ${ }^{\mathrm{a}}$, Shaobo Liang ${ }^{\mathrm{a}}$, Nicholas M. Guho ${ }^{\mathrm{b}}$, Andrea J. Hanson ${ }^{\mathrm{c}}$, Matthew W. Smith ${ }^{\mathrm{d}}$, \\ Manuel Garcia-Perez ${ }^{\mathrm{d}}$, Armando G. McDonald, \\ a, ${ }^{*}$ Renewable Materials Program, Department of Forest, Rangeland and Fire Sciences, University \\ of Idaho, Moscow, ID 83844-1132, USA \\ ${ }^{\mathrm{b}}$ Department of Civil Engineering, University of Idaho, Moscow, ID 83844-1022, USA \\ ${ }^{c}$ Department of Biological Sciences, University of Idaho, Moscow, ID 83844-3051, USA \\ ${ }^{\mathrm{d} B i o l o g i c a l ~ S y s t e m s ~ E n g i n e e r i n g, ~ W a s h i n g t o n ~ S t a t e ~ U n i v e r s i t y, ~ P u l l m a n, ~ W A ~ 99164, ~ U S A ~}$ \\ * Corresponding author. Tel.: +1 208885 9454; fax: +1 2088856226 . \\ E-mail address: armandm@uidaho.edu (A.G. McDonald).
}

\begin{abstract}
Polyhydroxyalkanoate (PHA) production generates a significant amount of residual bacterial biomass (RBB) after PHA extraction. The RBB as a zero-value waste contains proteins, carbohydrates, phenolics, and ash, which can be managed and converted to bio-oil and biochar products by pyrolysis. Thermogravimetric analysis (TGA) was used to investigate the thermodegradation kinetics of RBB and pyrolysis-GCMS studies were employed to determine potential chemical products. Pyrolysis was conducted on a laboratory-scale auger reactor at 500 ${ }^{\circ} \mathrm{C}$. The bio-oil and biochar yield were 28 and $46 \%$, respectively. The pyrolysis bio-oil was characterized by the combination of GCMS, high-pressure liquid chromatography (HPLC), and
\end{abstract}


electrospray ionization mass spectrometry (ESI-MS). The bio-oil was dominated by nitrogencontaining, hydrocarbons, and aromatic compounds. The biochar was studied for its specific surface area and pore size, chemical functionality by Fourier transform infrared (FTIR) and Raman spectroscopies, and butane absorption activity. Biochar was comprised of a large part of polycondensed phenolic and majorly disordered amorphous carbon.

Keywords: Residual bacterial biomass; polyhydroxyalkanoate; compositional analysis; bioproducts

\section{Introduction}

Driven by the awareness of environmental pollution by petroleum based plastics, the bioplastic market is expected to reach to 6.2 million metric tons globally by 2017 [1]. Within the diverse bioplastic family, polyhydroxyalkanoate (PHA) is a special group of polyesters produced by a wide variety of microorganisms as an internal (i.e., within bacterial cells) carbon and energy reservoir. Due to its good biocompatibility, biodegradability, and renewability, PHA has been widely used in biomedical, packaging, and agricultural areas [2,3].

Commercial PHAs are produced using pure or recombinant bacterial cultures at high cost (UD\$ 4.4-6.1 $\mathrm{kg}^{-1}$ ) [4], making it less competitive with conventional petroleum based plastics as bulk materials at the point of price. Recently, inexpensive carbon/nitrogen sources such as agricultural residues or industrial waste and woody biomass streams have become competitive carbon sources to reduce the PHA production cost by at least 50\% [5-8]. The use of mixed microbial cultures (MMCs) has been proposed as an ideal alternative to current commercial PHA production (recently reviewed by Laycock et al. [9]). However, the PHA production process from waste streams using MMCs generates relatively lower PHA content as compared with that 
from pure substrates and pure microbial cultures [3]. In our recent study, PHA (specifically polyhydroxybutyrate-co-hydroxyvalerate, $\mathrm{PHBV}$ ) was biosynthesized from fermented dairy manure by MMCs [7]. The PHBV content reached up to $40 \%$ of the dry cell weight with HV content ranging from 15 to $40 \mathrm{~mol} \%$. The remaining material, the residual bacterial biomass (RBB), is conventionally discarded as waste materials (> $60 \%$ of the biomass dry weight) potentially result in a valuable byproduct.

The RBB is primarily comprised of lysed bacterial cells; specifically, proteins, nucleic acids, carbohydrates, and lipids [10]. Consequently, disposal of this RBB resulting from PHA production is an issue. Given their diverse composition, opportunities exist to upgrade this material into useful bioproducts. Pyrolysis of biomass, mainly lignocellulosics (e.g., wood and herbaceous species), has gained considerable attention as an option for producing a crude bio-oil that can be further upgraded into drop-in fuels $[11,12]$. However, the pyrolysis of lignocellulosics carry some limitations: (i) derived pyrolysis bio-oil contains an abundance of oxygenated compounds and (ii) the bio-oil is too acidic [13]. Aside from lignocellulosic materials, other suitable feedstocks for pyrolysis include N-containing wastes, such as algae [14], manure [15, 16], potato peel [17], and activated sludge [18-23]. Of these, activated sludge is arguably the most similar to RBB, due to both being comprised primarily of bacteria. For example, Sánchez et al. studied sewage sludge, focusing on the effect of pyrolysis temperature $\left(350,450,550\right.$, and $\left.950{ }^{\circ} \mathrm{C}\right)$ on the composition of the bio-oils [22]. They obtained the liquid products (bio-oil and water) and biochar products with the yield of about $30 \%$ and 50\%, respectively. Different classes of compounds were identified in the oils by GCMS analysis, such as hydrocarbons (alkane and alkene), monoaromatic hydrocarbons (e.g., benzene, toluene, styrene, phenol, etc.), N-containing aromatic compounds (e.g., pyridine, alkyl pyridines, pyrrole, 
indole, and quinolones derivatives), aliphatic and aromatic nitriles, and carboxylic acids [22].

With these constituents, activated sludge has the potential to be used as a fuel oil after upgrading or as a source of commercially useful chemicals. Determining if the similar RBB holds the same potential, knowledge of the chemical composition and product distribution following pyrolysis is needed.

PHA was biosynthesized from a pilot-scale PHA bioreactor fed by fermented dairy manure liquor with MMCs from a waste water treatment plant. N-rich RBB waste was generated after PHA bioplastic was isolated. The objective of this study was to thermochemically convert (via pyrolysis) the RBB into value added bioproducts and minimize the biological waste and impact to the environment. The resulting pyrolysis products were collected and characterized. The pyrolysis bio-oil products were chemically investigated by a combination of GCMS, ESI-MS, and HPLC. The biochar was characterized by proximate, ultimate, butane activity, surface area, and FTIR and Raman spectroscopies.

In the present study, it is the first time utilizing RBB waste for value added bioproducts. Bio-oil production from RBB via pyrolysis provides an alternative to the growing interest in pyrolysis liquids produced from agricultural residues. The yield and compositions of bioproducts from pyrolysis were compared with other N-containing waste and biomass.

\section{Material and methods}

\subsection{Residual bacterial biomass (RBB) generated from PHA production process}

Biomass used in this study was collected from a pilot-scale PHA producing bioreactor fed with fermented dairy manure [7]. Briefly, dairy manure was collected from the University of Idaho North Farm Dairy and fed to a continuously operated $800 \mathrm{~L}$ anaerobic fermenter operated under 
a $24 \mathrm{~h}$ cycle time with solid and hydraulic retention times of $4 \mathrm{~d}$. Following solid-liquid separation by screening and settling, the volatile fatty acid rich liquid was pumped into the second and third stage $700 \mathrm{~L}$ bioreactors for PHA production. After PHA was accumulated in the bioreactor, biomass was recovered and suspended in $6.25 \%$ sodium hypochlorite to lyse the cells and cease metabolic activity during the recovery process [24]. PHA-rich biomass was centrifuged and frozen at $-20{ }^{\circ} \mathrm{C}$. Samples were lyophilized prior to extraction and characterization.

Lyophilized biomass $(500 \mathrm{~g})$ was washed with acetone $(4 \mathrm{~L})$ for $24 \mathrm{~h}$ to remove lipids, followed by Soxhlet extraction system with $\mathrm{CHCl}_{3}\left(2 \mathrm{~L} ; 60{ }^{\circ} \mathrm{C}\right)$ for $24 \mathrm{~h}$ to extract the PHBV bioplastic. The yield (from duplicate experiments) of crude PHBV, lipids, and RBB was in the range of 15 $26 \%, 5-10 \%$, and $60-80 \%$, respectively. The HV content of the PHBV copolymer was ranging from 15 to $40 \mathrm{~mol} \%$ as determined by ${ }^{1} \mathrm{H}$ NMR [7].

The RBB was vacuum-dried prior to use or analysis. A flow diagram showing the processes used and experiments performed is shown in Fig. 1.

\subsection{RBB characterization}

\subsubsection{Calorific value, proximate and ultimate analyses}

Calorific value of RBB sample was determined using a Parr oxygen bomb calorimeter (Model 1261 according to the ASTM D5865-04). Pre-dried biomass sample $(1.0 \mathrm{~g})$ was pressed into a pellet $(6 \mathrm{~mm} \varnothing)$ on a Carver Laboratory hydraulic press to a pressure of $15 \mathrm{MPa}$. The proximate analysis (ash, volatile matters, and fixed carbon) on vacuum-dried RBB was performed in accordance with ASTM standard E870-82. More specifically, the content of volatile matter (VM) was determined following 7 min of combustion in a muffle furnace at $950{ }^{\circ} \mathrm{C}$. Ash content was 
carried out at $580{ }^{\circ} \mathrm{C}$, and moisture content (MC) was measured using a moisture analyzer (HB43-S Mettler Toledo). Fixed carbon (FC) content was a calculated value by subtracting MC, $\mathrm{VM}$ and ash from 100. The ultimate (elemental) analysis for $\mathrm{C}, \mathrm{H}$ and $\mathrm{N}$ were determined using a CE-440 elemental analyzer (Exeter Analytical), and $\mathrm{O}$ was calculated by the difference of C, H, $\mathrm{N}$ and ash results from $100 \%$.

\subsubsection{Chemical composition}

The lipids from the RBB were extracted with $\mathrm{CH}_{2} \mathrm{Cl}_{2}$ and quantified according to the method of Osman et al. [25]. Carbohydrate content of lipid-free $\mathrm{RBB}$ after $\mathrm{CH}_{2} \mathrm{Cl}_{2}$ extraction was analyzed as previously described [26, 27]. In short, polysaccharides were first hydrolyzed into monosaccharides with $2 \mathrm{M}$ trifluoroacetic acid (TFA) at $105^{\circ} \mathrm{C}$ and then reduced by $\mathrm{NaBD}_{4}$ and followed by acetylation with acetic anhydride. The alditol acetate derivatives were analyzed by GCMS $_{\text {EI }}$ (FOCUS-ISQ, ThermoScientific). Separation was achieved using a BPX-70 capillary column $\left(30 \mathrm{~m} \times 0.25 \mathrm{~mm} \emptyset\right.$, SGE Analytical Science) with a temperature gradient from $190{ }^{\circ} \mathrm{C}$ (1 min) to $250{ }^{\circ} \mathrm{C}(20 \mathrm{~min})$ at a rate of $2{ }^{\circ} \mathrm{C} \mathrm{min}^{-1}$. The compounds were identified with authentic derivatized sugars and mass spectral analysis. The crude protein content was estimated from the measured $\mathrm{N}$ content (a multiple of 6.25 was assumed). The lignin content was determined on lipid-free RBB as acid insoluble (Klason) and acid soluble lignin as described by ASTM E175801 with the modification proposed by Liang and McDonald [28].

Amino acid composition (free and bound) was performed according to the method described by McDonald et al. [29]. Briefly, protein in the RBB (20 mg) was hydrolyzed in hydrochloric acid into amino acids, and then free/hydrolyzed amino acids were sequentially derivatized using acetylchloride/isobutanol (1:4 v/v) mixture followed by heptafluorobutylanhydride in $\mathrm{CH}_{2} \mathrm{Cl}_{2}$.

The heptafluorobutyl-isobutyl esters products were dissolved in $\mathrm{CHCl}_{3}\left(1 \mathrm{mg} \mathrm{mL}^{-1}\right)$ and 
analyzed by $\mathrm{GCMS}_{\mathrm{EI}}$ (PolarisQ iontrap, Thermo Electron Corp.). Separation was achieved on a ZB1 capillary column $(30 \mathrm{~m} \times 0.25 \mathrm{~mm} \emptyset$, Phenomenex $)$ using a temperature program from $40{ }^{\circ} \mathrm{C}$ to $250{ }^{\circ} \mathrm{C}$ at $5{ }^{\circ} \mathrm{C} \mathrm{min}^{-1}$. The eluted compounds were identified with authentic derivatized amino acids and mass spectral matching.

\subsubsection{Thermogravimetric analysis (TGA)}

TGA was performed on a TGA-7 (Perkin-Elmer) instrument. RBB samples (3-5 mg, in duplicates) were heated from 50 to $900{ }^{\circ} \mathrm{C}$ at rates of $5,10,20,30,40$, and $50 \mathrm{~K} \mathrm{~min}^{-1}$ under

nitrogen $\left(30 \mathrm{~mL} \mathrm{~min}^{-1}\right)$. TGA and differential thermogravimetry (DTG) data were analyzed using Pyris v8 software. Activation energy $(E)$ and pre-exponential factor $(A)$ were calculated according to ASTM E1641-07. The decomposition kinetics was assumed to be first-order to determine $E$ and $A$ as follows:

$\mathrm{E}=-(R / b) \times \Delta(\log \beta) / \Delta(1 / T)$

$\mathrm{A}=-\left(\beta^{\prime} / E_{\mathrm{r}}\right) \times R \times \ln (1-\alpha) \times 10^{a}$

where, $R$ is the gas constant, $b$ is the approximate derivative from ASTM E1641 numerical integration constants, $\beta$ is the heating rate at $\mathrm{K} \mathrm{min}^{-1}, \beta^{\prime}$ is the heating rate nearest the midpoint of the experimental heating rates at $\mathrm{K} \mathrm{min}^{-1}$, $\mathrm{T}$ is the temperature $(\mathrm{K})$ of the experimental heating rate at constant conversion, $E_{\mathrm{r}}$ is the refined value of Arrhenius $E, \alpha$ is the conversion value of decomposition, and $a$ is the approximation integral taken from ASTM E1641 of numerical integration constants.

\subsubsection{Pyrolysis GCMS analysis}

Analytical pyrolysis GCMS (Py-GCMS) was performed on RBB $(<0.1 \mathrm{mg})$ and pyrolyzed at $500{ }^{\circ} \mathrm{C}$ in He with a Pyrojector II unit (SGE Analytical Science), coupled to a FOCUS-ISQ 
$\mathrm{GCMS}_{\mathrm{EI}}$ (ThermoScientific). The compounds were separated on the RTx-5MS capillary column $\left(30 \mathrm{~m} \times 0.25 \mathrm{~mm} \varnothing\right.$, Restek) with temperature programed to be 40 to $250{ }^{\circ} \mathrm{C}$ at $5{ }^{\circ} \mathrm{C} \mathrm{min}{ }^{-1}$. The eluted compounds were identified by their mass spectra, authentic standards, and with the NIST 2008 library matching. The relative abundance of each compound was calculated relative to the $\mathrm{CO}_{2}$ peak [28].

\subsection{Bio-oil and biochar production from RBB pyrolysis}

Pyrolysis was conducted at $0.2 \mathrm{~kg} \mathrm{~h}^{-1}$ feed rate (K-Tron weight loss twin-screw feeder) in a custom built auger reactor $(\Phi 5 \mathrm{~cm} \times 90 \mathrm{~cm})$ at $500{ }^{\circ} \mathrm{C}$ with $\mathrm{N}_{2}$ purge $\left(6 \mathrm{~L} \mathrm{~min}^{-1}\right)$, and the temperature of transfer tube was set at $450{ }^{\circ} \mathrm{C}$ (shown schematically in Fig. 2) [17]. The auger speed was adjusted to obtain a residence time of $8 \mathrm{~s}$. Vapors were condensed through a two stage ice-water-cooled tube and shell condensing system and bio-oil was recovered and yield recorded. Biochar was collected at the end of reactor and yield recorded.

The $\mathrm{pH}$ value of the pyrolysis bio-oil was measured with a portable $\mathrm{DO} / \mathrm{pH}$ meter (Orion-3-Star). Simplifying the characterization, the bio-oil ( $5 \mathrm{~g})$ was vigorously mixed with water (10 $\mathrm{g})$ for 15 min and centrifuged for $30 \mathrm{~min}$ with the centrifugal force of $3900 \mathrm{~g}$. The bio-oil was $100 \%$ dispersible in water, which is noted to be WD fraction. The WD bio-oil fraction was further extracted by adding diethyl ether $(40 \mathrm{~mL})$ to obtain ether-soluble (ES) and aqueous (AQ) fractions (Fig. 1).

\subsection{Bio-oil characterization}

GCMS (FOCUS-ISQ, Thermoscientific) was used to analyze the ether soluble (ES) fractions (1 $\mathrm{mg} / \mathrm{mL})$ with anthrancene added as an internal standard $\left(50 \mu \mathrm{g} \mathrm{mL}^{-1}\right)$, in triplicate, where the separation was achieved using an RTx-5MS capillary column $(30 \times 0.25 \mathrm{~mm} \emptyset$, Restek $)$. The 
temperature program was set to be from 40 to $320^{\circ} \mathrm{C}$ at $5{ }^{\circ} \mathrm{C} \mathrm{min}^{-1}$. Compounds were identified as described above for pyrolysis GCMS.

The AQ fraction was analyzed by HPLC, in triplicate, using a Rezex ROA organic acid column $(7.8 \times 30 \mathrm{~cm}$, Phenomenex) equipped with a differential refractive index detector (ERC-5710, ERMA), on elution with $0.005 \mathrm{~N}$ aqueous sulfuric acid $\left(0.5 \mathrm{~mL} \mathrm{~min}^{-1}\right)$ at $65^{\circ} \mathrm{C}$. Data were acquired and analyzed using the N2000 chromatography software (Science Technology Inc., China).

The WD fraction was also analyzed directly by ESI-MS following dissolution in $1 \%$ acetic acid in methanol. The sample was introduced to a Finnigan LCQ-Deca instrument (Thermoquest) at a flow rate of $10 \mu \mathrm{L} \mathrm{min}^{-1}$. Both negative and positive ion ESI-MS scans in the range $m / z$ 50-2000 were performed for the same sample. The ion source and capillary voltages were $4.48 \mathrm{kV}$ and 47 $\mathrm{V}$, respectively, and the temperature was $275^{\circ} \mathrm{C}$. Both the number average molar mass $\left(M_{\mathrm{n}}\right)$ and the weight average molar mass $\left(M_{\mathrm{w}}\right)$ were computed using all the ions detected in the ESI-MS spectra of the ion with higher intensity. $M_{\mathrm{n}}$ and $M_{\mathrm{w}}$ were computed as $M_{\mathrm{n}}=\Sigma M_{\mathrm{i}} N_{\mathrm{i}} / \Sigma N_{\mathrm{i}}$ and $M_{\mathrm{w}}=$ $\Sigma M_{\mathrm{i}}^{2} N_{\mathrm{i}} / \Sigma M_{\mathrm{i}} N_{\mathrm{i}}$, respectively, where the $M_{\mathrm{i}}$ is the $m / z$ and $N_{\mathrm{i}}$ is the intensity of the $\mathrm{i}^{\text {th }}$ ion.

The boiling point distribution of bio-oil was determined by TGA from 110 to $900{ }^{\circ} \mathrm{C}$ at $10 \mathrm{~K}$ $\min ^{-1}$ under $\mathrm{N}_{2}$ flow of $30 \mathrm{~mL} \mathrm{~min}^{-1}$.

\subsection{Biochar characterization}

Biochar was vacuum dried prior to analysis. The butane activity (BA) of biochar was determined according the method of ASTM D5742-95 where dry biochar $(16.7 \pm 0.05 \mathrm{~mL}$, of known weight) was placed into the sample tube flushed with butane $\left(250 \pm 5 \mathrm{~mL} \mathrm{~min}^{-1}\right)$ until a constant weight gain was obtained. The sample tube was placed in a water bath at $25 \pm 0.2^{\circ} \mathrm{C}$. The proximate 
analysis and calorific values of biochar samples were determined according to the aforementioned methods.

The specific surface area of the bacterial biomass char $(0.10 \mathrm{~g}$, in duplicate) was determined by $\mathrm{N}_{2}$ and $\mathrm{CO}_{2}$ (g) adsorption using a TriStar II plus automatic physisorption analyzer (Micromeritics Instrument Corporation). Before analysis the sample was vacuum degassed for 10 h at $200{ }^{\circ} \mathrm{C} . \mathrm{N}_{2}$ isotherms were collected at $77 \mathrm{~K}$ and a partial pressure range of $0.0001-0.99$, within this range 50 absorption and 35 desorption points were specified to fully resolve the isotherm. $\mathrm{CO}_{2}$ isotherms were collected at $273 \mathrm{~K}$ and a partial pressure range of $0.00001-0.03$ with 75 points specified for the absorption isotherm. BET analysis was used to determine the apparent surface area (SA) from the $\mathrm{N}_{2}$ isotherm using data from points collected at partial pressures between .001 and 0.1. SA, micropore volume $\left(\mathrm{V}_{\mathrm{mi}}\right)$, and average pore width $\left(\mathrm{W}_{\text {avg }}\right)$ were determined by the Dubinin-Radushkevich (DR) equation fit to data points between $2<\log$ $\left(\mathrm{P}_{0} \mathrm{P}^{-1}\right)^{2}<6$ for both $\mathrm{N}_{2}$ and $\mathrm{CO}_{2}$ isotherms. $W_{\text {avg }}$ was calculated from the characteristic binding energy $\left(E_{o}\right)$ given by the DR equation [30].

$W_{\text {avg }}(\mathrm{nm})=10.8 /\left(E_{o}-11.4 \mathrm{~kJ} \mathrm{~mol}^{-1}\right)$

Total pore volume $\left(\mathrm{V}_{\mathrm{T}}\right)$ was determined from the maximum adsorption quantity at a partial pressure of approximately 0.99 for the $\mathrm{N}_{2}$ isotherms. Total mesopore volume $\left(\mathrm{V}_{\mathrm{me}}\right)$ was determined by subtracting the micropore volume determined by $\mathrm{N}_{2}$ from $\mathrm{V}_{\mathrm{T}}$.

The RBB and biochar samples were characterized by FTIR spectroscopy using a Thermo Scientific iS5 spectrometer with an attenuated total reflection (ATR) iD5 probe (ZnSe). Samples were analyzed in triplicate, absorbance spectra averaged and baseline corrected using Omnic v9.0 software (ThermoScientific). 
Raman spectra (9 replicates) of RBB biochar were acquired on Alpha 300 R confocal Raman microscope (Witec) spectrometer with $532 \mathrm{~nm}$ excitation, $0.5 \mathrm{~s}$ integration time and $10 \mathrm{scans}$. The spectra were averaged and baseline corrected using Omnic v9 (ThermoScientific) software. Band fitting of the spectrum was performed using a Gaussian function with Igor Pro v6.3 (Wavemetrics) software.

\section{Results and discussion}

\subsection{RBB characteristics}

\subsubsection{Chemical composition, proximate, ultimate, and calorific value analyses}

Table 1 shows the results obtained from the proximate, ultimate and chemical composition analyses, and the calorific values of the RBB. The RBB has a high amount of ash (21\%), which was probably due to accumulated minerals (from the fermented dairy manure) that provided nutrients to the mixed microbial culture growth necessary for PHA biosynthesis. Additionally, the FC and VM of this RBB were close to the proximate analysis of sewage sludge by Shen and Zhang [23].

The ultimate analysis shows that C (36\%) and $\mathrm{H}(5 \%)$ contents of RBB were slightly lower than hybrid poplar [17] and herbaceous biomass (e.g. corn stover and switchgrass) [12]. The calorific value of RBB was $16.1 \mathrm{MJ} \mathrm{kg}^{-1}$, which is comparable with the values for some hardwoods (13.5-

19.4 $\mathrm{MJ} \mathrm{kg}^{-1}$ ) [31], but higher than those for seaweed algae samples (10.6-13.5 $\mathrm{MJ} \mathrm{kg}^{-1}$ ) [14], as well as a mixture of mixed-culture algal biomass and swine manure [32]. This observed increase in calorific value was due to the significant $\mathrm{N}$ (attributed to protein) content of RBB which exceeded $5 \%(\mathrm{C} / \mathrm{N}($ mole $)=7.52)$, and is comparable with other N-rich biomass, such as 
activated sludge from waste water treatment and sewage sludge $[21,33]$. The $\mathrm{C} / \mathrm{H}$ and $\mathrm{C} / \mathrm{O}$ ratios of RBB were 0.58 and 1.52 , respectively.

The RBB contained approximately $21 \mathrm{wt} \%$ carbohydrate, $27 \mathrm{wt} \%$ acid insoluble residues (e.g., lignin/protein), and $10 \mathrm{wt} \%$ lipids (fatty acids and PHBV). It is worth noting that protein content of this RBB was > $30 \mathrm{wt} \%$; similarly high protein content has been observed in activated sludge from waste water treatment processer $[10,20,33]$. Taken together, these findings suggest that the RBB could be a potential waste stream to be converted into more valuable bio-products through pyrolysis.

\subsubsection{Protein and amino acid analysis}

With protein constituting a major portion of the RBB, further distribution between free and bound amino acids is necessary to understand the origin of the pyrolysis products. The RBB contained 13 free amino acids, and upon hydrolysis, 16 amino acids were detected. The most abundant free amino acid was glutamic acid, followed by alanine and aspartic acid. The three major amino acids after hydrolysis, were glutamic acid, aspartic acid, and lysine. All amino acids have the same peptide backbone; similar degradation (e.g., decarboxylation and deamination) could be experienced for either free or bound form.

\subsubsection{TGA/DTG analysis of waste biomass feedstock}

TGA was conducted to investigate the thermal degradation behavior (e.g., pyrolysis temperature and decomposition kinetics) of RBB (Fig. 3). The thermal degradation of RBB occurred in three distinctive stages between 50 and $600{ }^{\circ} \mathrm{C}$ : (i) $<200{ }^{\circ} \mathrm{C}$, (ii) $200-375{ }^{\circ} \mathrm{C}$, and (iii) $>375{ }^{\circ} \mathrm{C}$. The first two stages could be attributed to the moisture/volatile matter evaporation and the decomposition of carbohydrates $\left(150-350{ }^{\circ} \mathrm{C}\right)$ and cellulosic polysaccharides $\left(275-350{ }^{\circ} \mathrm{C}\right)$. The 
third stage was possibly due to lignin degradation $\left(250-500^{\circ} \mathrm{C}\right)$. Lipids residue would occur through the whole temperature range $\left(200-600^{\circ} \mathrm{C}\right)[28,34,35]$. Proteins from bacteria decompose in a temperature range of 300 to $400^{\circ} \mathrm{C}$ [18]. About $21 \%$ char/ash was observed, which is in accordance with ash content determination.

The activation energy, $E$, before $75 \%$ conversion of samples at $5 \%$ conversion intervals were according to ASTM methods. The average $E$ and $A$ values were $199 \mathrm{~kJ} \mathrm{~mol}^{-1}$ and $1.07 \times 10^{24}$, respectively. These parameters were similar to other lignocellulosic biomass $[28,36]$ and protein-rich sewage sludge [18].

\subsubsection{Py-GCMS analysis of residual bacterial biomass}

Analytical Py-GCMS at $500{ }^{\circ} \mathrm{C}$ was used to identify potential pyrolysis products (Table 3). A total of 32 pyrolysis compounds were identified with the most abundant products being $\mathrm{CO}_{2}$ followed by acetic acid (9.8\%), docosenamide (10.9\%), and acetaldehyde (9.1\%). Approximately $20 \%$ carbohydrate derived compounds (including acetic acid) were identified. Acetaldehyde could be generated from the thermal decomposition of protein or free amino acid, especially alanine [37], which was the second most abundant amino acid identified in the RBB (Table 2). A small but noteworthy amount of diketopiperazine $(2.1 \%)$ was identified, which is caused by the dimerization of two glycine units $[38,39]$. Several fatty acids compounds such as undecenoic acid (5.0\%) and hexadecenoic acid (4.4\%) were produced, which were derived from lipids in the RBB. Aromatic hydrocarbons, phenols, guaiacol and syringol were also detected. For example, guaiacol and syringol (and their derivatives) comprised 12.8 and $7.8 \%$ of the pyrolysis products, respectively. This finding supports the presence of lignin or lignin fragments in the RBB [40] and reinforces the chemical compositional analysis. Lignin is likely carried over as fine particles from the fermented dairy manure liquor feed to the PHA bioreactor. Furthermore, some of these 
aromatic compounds (e.g. phenol) may originate from aromatic amino acids, such as phenylalanine and tyrosine [41]. Additionally, N-containing compounds (e.g., pyrrole, benzonitrile, indole, and docosenamide, etc.) derived from protein were produced, constituting approximately $36 \%$ of the pyrolysis products. This agrees with the ultimate $(\mathrm{C}, \mathrm{H}$, and $\mathrm{N})$ and chemical compositional analyses of the RBB (Table 1). Regarding indoles and aromatic nitriles (e.g., benzonitrile), these products could also be possibly derived from protein decomposition. Pyrrole, indole and their derivatives have been observed in pyrolytic oil from sewage sludge [22, 42]. The indole derivatives were possibly formed from pyrolysis of tryptophane, while pyrrole derivatives were from serine and asparagines [43, 44].

3,5-Diethylpyridin-4-amine was also present at a level of $2.6 \%$ of all the compounds detected. The pyrolysis product octahydrodipyrrolo[1,2-a:1', 2'-d]pyrazine-5,10-dione (OHDPPD) was most likely a proline condensation product $[42,45]$. Acetamide $(4.4 \%)$ was also produced and could arise from microbial cell membranes and amino sugars [42]. A small amount of butenoic $(1.6 \%)$ and pentenoic acids $(1.7 \%)$ were identified, and likely arose from the thermal degradation of residual PHBV in the RBB.

\subsection{Pyrolysis yield and products fractionation}

TGA analysis of RBB showed almost complete decomposition by $500{ }^{\circ} \mathrm{C}$, therefore, pyrolysis was conducted at this temperature. The bio-oil and biochar yields and properties (e.g., pH and water solubility) were recorded. A bio-oil yield of $28 \%$ was obtained, which was similar to that from sewage sludge (30\%) [22]. A biochar yield of $46 \%$ was obtained, which lied in the range of $36-56 \%$ that was observed from pyrolyzed activated sludge (thickened excess activated sludge, dewatered digested sludge, and dried excess activated sludge) [21]. These high biochar yields are ascribed to the high ash content of the biomass. The nature of the biomass, the heat transfer rate, 
and efficiency of the pyrolysis reactor can influence bio-oil and biochar yields [17]. The efficiency of the transfer tube can be potentially improved to condense and recover more bio-oil. Moreover, the RBB pyrolysis product yields and characteristics can be optimized by varying the pyrolysis parameters (residence time, temperature, etc). For example, pyrolysis temperature could be increased to produce biochar with relatively higher surface areas.

The bio-oil was shown to have a high $\mathrm{pH}$ of 8.2 as compared to woody lignocellulosic biomass pyrolysis bio-oils, which are acidic $(\mathrm{pH} \sim 2.5)$ [11]. This high $\mathrm{pH}$ was most likely a result of a high amine content of the bio-oil which was derived from protein. Compared with pyrolysis oil from low-protein lignocellulosic biomass, the lower acidity of bio-oil from RBB could make it favorable for direct use as boiler fuel. The bio-oil was highly dispersible in water (WD fraction) and this is probably due to the polar pyrolysis products derived from proteins and carbohydrates [13]. Due to its good water dispersibility, nitrogen-rich bio-oil could be fed back for PHA biosynthesis which typically occurs under aqueous medium.

The WD fraction was partitioned into ether (ES, 15\% w/w) and aqueous (AQ, 85\% w/w) fractions (Fig. 1) that were characterized by GCMS and HPLC, respectively, to simplify the identification of the generated compounds (Table 4).

The WD fraction was comprised of carbohydrate derived products such as acetic acid (41.3\%), levoglucosan (3.1\%), and formic (1.9\%) and propanoic (1.9\%) acids. About $27.3 \%$ of the products were N-based compounds, such as imidazole and pyrrole derivatives, and were similar to the Py-GCMS analysis. This further confirmed thermal decomposition or recombination of amino acids (free or hydrolysates from proteins) during pyrolysis. Moreover, some aromatic hydrocarbons were formed, including phenol, methylphenols, guaiacol, syringol and toluene 
derivatives were also formed. According to Fabbri et al. [41], phenols are characteristic thermal fragmentation products of free aromatic amino acids such as phenylalanine and tyrosine.

Guaiacol and syringol based compounds are derived from lignin. In addition to compounds formed from simple cleavage of amino acids, the formation of 5-methyl-2,4-imidazolidinedione is possibly from protein pyrolysis by lactam ring formation. This compound was also observed in keratin pyrolysis products [46].

The average molar mass $\left(M_{\mathrm{w}}\right.$ and $\left.M_{\mathrm{n}}\right)$ of the pyrolysis bio-oil was obtained by the ESI-MS analysis. The positive and negative ion ESI-MS spectra are shown in Fig. 4. The positive ion MS spectrum was dominated by $<m / z 400$ ions than those in the negative mode $(<m / z 300)$. The $M_{\mathrm{w}}$ and $M_{\mathrm{n}}$ determined in positive mode were 496 and $592 \mathrm{~g} \mathrm{~mol}^{-1}$, respectively, with a polydispersity ( $\mathrm{PD}=M_{\mathrm{w}} / M_{\mathrm{n}}$ ) close to 1.2 . The $M_{\mathrm{w}}, M_{\mathrm{n}}$, and $\mathrm{PD}$ values determined from the negative ion spectrum were respectively, $394 \mathrm{~g} \mathrm{~mol}^{-1}, 258 \mathrm{~g} \mathrm{~mol}^{-1}$, and 1.5 . These results clearly show that the products were mono- to oligo-meric compounds. The molar mass was higher than other biomass types, i.e., hybrid poplar and potato peel waste [17]. More N-containing compounds are observed in the positive mode, whereas more oxygen-rich compounds were seen in the negative mode. In the positive mode (Fig. 4a) protonated species $[\mathrm{M}+\mathrm{H}]^{+}$were observed and tentatively assigned at $m / z 97\left(\mathrm{C}_{5} \mathrm{H}_{9} \mathrm{~N}_{2}\right), 111\left(\mathrm{~N}_{6} \mathrm{H}_{11} \mathrm{~N}_{2}\right), 125\left(\mathrm{C}_{7} \mathrm{H}_{13} \mathrm{~N}_{2}\right), 139\left(\mathrm{C}_{8} \mathrm{H}_{15} \mathrm{~N}_{2}\right), 153$ $\left(\mathrm{C}_{9} \mathrm{H}_{17} \mathrm{~N}_{2}\right.$ or $\left.\mathrm{C}_{9} \mathrm{H}_{12} \mathrm{O}_{2}\right), 167\left(\mathrm{C}_{10} \mathrm{H}_{19} \mathrm{~N}_{2}\right), 180\left(\mathrm{C}_{10} \mathrm{H}_{14} \mathrm{O}_{2} \mathrm{~N}\right), 197\left(\mathrm{C}_{11} \mathrm{H}_{19} \mathrm{O}_{2} \mathrm{~N}\right), 209\left(\mathrm{C}_{12} \mathrm{H}_{19} \mathrm{O}_{2} \mathrm{~N}\right)$, $223\left(\mathrm{C}_{13} \mathrm{H}_{21} \mathrm{O}_{2} \mathrm{~N}\right), 231\left(\mathrm{C}_{14} \mathrm{H}_{19} \mathrm{ON}_{2}\right)$, and $253\left(\mathrm{C}_{16} \mathrm{H}_{17} \mathrm{ON}_{2}\right)$. These compounds were also found in pyrolysis products of N-containing species of switchgrass [47] and sewage sludge [22]. They were possibly derived from protein or free amino acid of the RBB. For example, the compound $\mathrm{C}_{14} \mathrm{H}_{19} \mathrm{ON}_{2}$ is likely a dipeptide of aspartic acid $\left([\mathrm{M}+\mathrm{H}]^{+}=133\right.$, Table 2$)$. The peak at $\mathrm{m} / z$, 82 was assigned to methylpyrrole and compliments the findings from the Py-GCMS analysis. Major 
peaks observed in the negative ion spectrum $\left([\mathrm{M}-\mathrm{H}]^{-}\right)$with tentative assignment include $\mathrm{m} / \mathrm{z}$ at $109\left(\mathrm{C}_{6} \mathrm{H}_{5} \mathrm{O}_{2}\right.$, benzenediol $), 123\left(\mathrm{C}_{7} \mathrm{H}_{7} \mathrm{O}_{2}\right.$, guaiacol), $137\left(\mathrm{C}_{8} \mathrm{H}_{10} \mathrm{O}_{2}\right), 149\left(\mathrm{C}_{9} \mathrm{H}_{9} \mathrm{O}_{2}\right.$, vinyl guaiacol), $191\left(\mathrm{C}_{7} \mathrm{H}_{11} \mathrm{O}_{6}\right)$, and $207\left(\mathrm{C}_{7} \mathrm{H}_{11} \mathrm{O}_{7}\right)$. The presence of these compounds supports the presence of phenolics and lignin in the RBB, which could be carried over from the fermented dairy manure liquor fed for the PHBV biosynthesis.

The boiling point distribution of the bio-oil was evaluated using TGA. This method was considered a miniature "distillation" unit according to Chen et al. [32]. The boiling temperature range was calibrated with an alkane wax standard $\left(\mathrm{C}_{10}-\mathrm{C}_{44}\right)$. Table 5 shows the major weight loss ( 89\%) of pyrolysis bio-oil occurred below $220{ }^{\circ} \mathrm{C}$. This indicated the bio-oil was mainly comprised of small compounds $\left(<\mathrm{C}_{12}\right)$. The coke oil with boiling point ranging from 25 to 200 ${ }^{\circ} \mathrm{C}$ can be used as bottle gas (chemicals) and gasoline [32]. At this stage, the RBB could become an attractive potential for bio-oil feedstock yet, nitrogen remains in the pyrolysis products, which should be removed in the subsequent chemical upgrading process. Therefore, this oil can be potentially upgraded or refined for transportation fuels and chemicals production.

\subsection{Biochar characterization}

FTIR spectroscopic analysis was used to investigate the chemical structure of biochar samples, while the raw biomass sample was analyzed for comparison (Fig. 5). The band assignments are summarized in Table 6. The broad band in the region of $3600-3200 \mathrm{~cm}^{-1}$ is attributed to the $\mathrm{O}-\mathrm{H}$ (e.g., water, alcohol, and phenol) and $\mathrm{N}-\mathrm{H}$ (amines) stretching vibrations [20]. For example, the $\mathrm{N}-\mathrm{H}$ stretching (amide II) vibration at 3380-3304 $\mathrm{cm}^{-1}$ was observed in the RBB (Fig. 5a), whereas it was not seen in the biochar sample. This indicated that the $\mathrm{N}$-containing protein was mostly converted into pyrolysis bio-oil products. Aliphatic bands $\mathrm{C}-\mathrm{H}\left(\mathrm{CH}_{3}\right.$ and $\left.\mathrm{CH}_{2}\right)$ stretching vibrations between 2950 and $2850 \mathrm{~cm}^{-1}$ were present in both RBB and biochar samples. The 
weak band at $1724 \mathrm{~cm}^{-1}$ in $\mathrm{RBB}$ sample could be from the $\mathrm{C}=\mathrm{O}$ stretching of $\mathrm{PHBV}$ bioplastic or lipid residues (fatty acids derivatives) (Fig. 5a) [48]. The broad band at $1641 \mathrm{~cm}^{-1}$ (Fig. 5a) was from Amide $\mathrm{I}(\mathrm{C}=\mathrm{O}$ stretching $)$, while the one at $1538 \mathrm{~cm}^{-1}$ was ascribed to the $\mathrm{C}-\mathrm{N}$ stretching and $\mathrm{N}-\mathrm{H}$ in-plane bending absorption due to Amide II of secondary amide in protein, respectively, which was not present in the spectra of the biochar (Fig 5b). The bands in the RBB between 1300 and $1500 \mathrm{~cm}^{-1}$ (i.e. 1451 and $1416 \mathrm{~cm}^{-1}$ ) could be assigned to the deformation of $\mathrm{CH}_{2}$ and $\mathrm{CH}_{3}$ groups (Fig. 5a). The small band at $1232 \mathrm{~cm}^{-1}$ was attributed to $\mathrm{C}-\mathrm{O}$ stretching and O-H bending vibrations of carboxylic acids [20].

The broad band centered at $3338 \mathrm{~cm}^{-1}$ in biochar sample was from $\mathrm{O}-\mathrm{H}$ group stretching (Fig. 5b). The broad absorption band in biochar from 1700 to $1300 \mathrm{~cm}^{-1}$ (centered at $1586 \mathrm{~cm}^{-1}$ and a shoulder at $1510 \mathrm{~cm}^{-1}$ ) was assigned to $\mathrm{C}=\mathrm{C}$ skeletal vibration of the aromatic ring of lignin. Hence, the biochar sample could be comprised of a large part of polycondensed phenolic structures. The intense band centered at $1052 \mathrm{~cm}^{-1}$ for both RBB and biochar sample was assigned to $\mathrm{C}-\mathrm{O}$ and $\mathrm{C}-\mathrm{O}-\mathrm{C}$ stretching of carbohydrates. As stated earlier, the biomass is comprised of a large amount of bacterial constituents (nucleic acids, proteins, carbohydrates and lipids).

The proximate analysis, BA, calorific value, and surface area of biochar samples are given in Table 1 . The biochar had an ash, VM, and FC content of $60 \%, 18 \%$, and $22 \%$, respectively. The ratio of VM and FC of the biochar sample was much higher than that of hybrid poplar and potato peel waste (PPW). This could be contributed to the relatively lower extent of condensed aromatic structures (number of aromatic C's per aromatic cluster) [17]. The calorific value for biochar was $20 \mathrm{MJ} / \mathrm{kg}$, which is similar to the biochar samples obtained from pyrolysis of PPW. BA is an indirect measure of surface area and adsorption of alkane for activated carbon. The BA value of 
pyrolysis biochar was $2.1 \%$. This value was lower than commercial activated carbon ( 25\%) [49], possibly due to lower total surface area. Higher pyrolysis temperature would likely increase BA as well as carbonization or ozonolysis [17, 50].

Gas adsorption isotherms, Fig. 6, indicate that the predominant pore structures in the RBB biochar are microporous. Analysis of the $\mathrm{CO}_{2}$ adsorption isotherm by the $\mathrm{DR}$ equation identifies a SA of $102 \pm 2 \mathrm{~m}^{2} \mathrm{~g}^{-1}$. The SA determined by $\mathrm{N}_{2}$ absorption was considerably lower, but shows strong agreement when calculated by either the BET or DR equation, $7.7 \pm 0.3 \mathrm{~m}^{2} \mathrm{~g}^{-1}$ or $8.1 \pm 0.6$ $\mathrm{m}^{2} \mathrm{~g}^{-1}$ respectively. The SA determined by $\mathrm{N}_{2}$ is consistent with the results obtained for sewage sludge pyrolysis biochar $\left(10.8 \mathrm{~m}^{2} \mathrm{~g}^{-1}\right)$ produced at $500{ }^{\circ} \mathrm{C}[51]$. The low SA value corroborates the low BA value obtained for this biochar.

The $\mathrm{V}_{\mathrm{mi}}$ determined by $\mathrm{N}_{2}$ was low, only $0.0029 \pm 0.002 \mathrm{~cm}^{3} \mathrm{~g}^{-1}$. In Fig. 6, the hysteresis seen in the $\mathrm{N}_{2}$ isotherm indicates that much of the pore volume detected is located within mesopores. This is confirmed by a $\mathrm{V}_{\mathrm{T}}$ of $0.046 \pm .001 \mathrm{~cm}^{3} \mathrm{~g}^{-1}$. When compared with $\mathrm{V}_{\mathrm{mi}}\left(\mathrm{N}_{2}\right)$ a $\mathrm{V}_{\mathrm{me}}$ of 0.043 $\pm .003 \mathrm{~cm}^{3} \mathrm{~g}^{-1}$ was obtained. More complete analysis of the microporous region by $\mathrm{CO}_{2}$ results in $\mathrm{a} \mathrm{V}_{\mathrm{mi}}\left(\mathrm{CO}_{2}\right)$ of $0.041 \pm 0.001 \mathrm{~cm}^{3} \mathrm{~g}^{-1}$. Analysis of the $E_{o}$ confirms that the micropores determined by $\mathrm{CO}_{2}$ were largely inaccessible to $\mathrm{N}_{2}$. Using the $\mathrm{DR}$ equation a $\mathrm{W}_{\text {avg }}$ of $0.6 \mathrm{~nm}$ was determined for pores probed by $\mathrm{CO}_{2}$ absorption. In comparison, the $\mathrm{E}_{\mathrm{o}}$ for $\mathrm{N}_{2}, 11.0 \pm 0.8 \mathrm{~kJ} \mathrm{~mol}^{-}$ ${ }^{1}$, was too low to be assessed by the DR equation, a result of substantially larger average pore size.

Ultimate analysis showed $27.7 \%$ of $\mathrm{C}, 1.2 \%$ of $\mathrm{H}$, and $4.9 \%$ of $\mathrm{N}$ in the biochar sample. Due to the high ash $(60 \%)$ content the $\mathrm{O}$ content was estimated at 5.9\%. The biochar can be used for soil 
amendment to enhance soil aggregation, water holding capacity, and organic carbon content. Compared to the parent biomass feedstock, lower $\mathrm{C}, \mathrm{H}$, and $\mathrm{N}$ was found in biochar. The $\mathrm{C} /$ Hratio was increased by $230 \%$ in biochar as compared to parent RBB, likely as a result of increasing content of aromatic compounds in the biochar sample. The $\mathrm{C} / \mathrm{O}$ ratio of the biochar sample was $410 \%$ higher than the parent RBB. A similar result was found in one previous study [13], pyrolytic deoxygenation of the high protein feedstock, such as defatted pennycress presscake which produced a pyrolysis products with a relatively higher $\mathrm{C} / \mathrm{O}$ ratio. The $\mathrm{C} / \mathrm{N}$ ratio was lower in biochar sample than that of RBB, which further confirmed the denitrogenation via deamination of protein and amino acids. Considering the $\mathrm{N}$ balance, the non-condensable gas fraction also contained some of the $\mathrm{N}$ from the starting biomass, possibly in the form of $\mathrm{NH}_{3}$.

Raman spectroscopy was performed on the biochar to obtain information on the structure of this carbonaceous material. The spectrum showed two broad bands at Raman shift of $1355 \mathrm{~cm}^{-1}$ and $1585 \mathrm{~cm}^{-1}$, which are respectively assigned to the D-band (amorphous or disordered C) and Gband (graphitic crystallites) of carbon (Fig. 7) [52]. These spectral bands are consistent with Raman spectra of biochar derived from pyrolyzed sewage sludge [51]. An estimation of disordered carbon in the sample was calculated from the ratio of $\mathrm{D} / \mathrm{G}$ band intensity $\left(\mathrm{I}_{\mathrm{D}} / \mathrm{I}_{\mathrm{G}}\right)$ to be 1.3. The $I_{D} / I_{G}$ value obtained was in the range of values for biochar (0.8-1.5) from various biomasses pyrolyzed around $500{ }^{\circ} \mathrm{C}[52,53]$, however was lower than sewage sludge biochar (5.7) produced at $500{ }^{\circ} \mathrm{C}[51]$. These results show that the RBB biochar is mainly disordered amorphous carbon. 


\section{Conclusions}

In this study, residual bacterial biomass (RBB) from an MMC-based PHA production process was characterized for the chemical composition and thermal decomposition. The RBB was comprised of carbohydrate, lignin, and N-rich compounds (protein/nucleic acid). Similar calorific values and thermal decomposition kinetic energy further showed the RBB could be suitable for use as a renewable fuel. Pyrolysis was successfully used to convert the RBB into biooil and biochar products. The bio-oil yield (28\%) was relatively low compared to that of lignocellulosic biomass. Biochar yield (46\%) was high due to high ash and protein contents of RBB. Py-GCMS showed pyrolysis products were comprised of aromatics, hydrocarbons, and Ncontaining compounds. The primary compounds identified in the bio-oil can be grouped into different classes: hydrocarbons, such as mono-aromatic hydrocarbons and phenolic compounds, which include toluene and phenolic compounds; aliphatic ketone, including pentanone and cyclopentanedione; nitrogen and oxygen containing aromatic compounds, such as pyrrole, indole, and pyridinyl products; aliphatic compounds and amines; and carboxylic acids. This preliminary study shows the RBB can be utilized to produce co-products to improve the economic viability of PHA production. Meantime, the results help understand the utilization of dairy manure as a feedstock for PHA production, for example, phenolics and lignin seemed originated from the fermented liquor. Future research will focus on optimizing pyrolysis operational parameters (temperature and residence time) to improve the bio-oil or biochar yields and quality. Nitrogen-rich pyrolysis oil could be considered as a potential feedstock for PHA production in the future. 


\section{Acknowledgement}

The authors would like to acknowledge: (i) the financial support from a USDA-NIFA grant 2012-68002-19952, (ii) Idaho State Board of Education grant IF11-012 for supporting the construction of the PHA pilot plant, (iii) Dr. Erik R. Coats (Department of Civil Engineering, University of Idaho) for kindly providing PHA biomass, and (iv) NSF grant DMR-0619310 for supporting the purchase of the alpha 300 Raman spectrometer.

\section{References:}

[1] G.-Q. Chen, M.K. Patel, Plastics derived from biological sources: present and future: A technical and environmental review, Chem Rev, 112 (2012) 2082-2099.

[2] E. Bugnicourt, P. Cinelli, A. Lazzeri, V. Alvarez, Polyhydroxyalkanoate (PHA): Review of synthesis, characteristics, processing and potential applications in packaging, Express Polym Lett, 8 (2014) 791-808.

[3] A.D. Allen, F.O. Ayorinde, B.E. Eribo, Non-edible vernonia galamensis oil and mixed bacterial cultures for the production of polyhydroxyalkanoates, Mod Chem Appl, 2 (2014) 3842 .

[4] D. de Guzman, (2010) Available at: http://www.icis.com/Articles/2010/2010/2025/9402443/bioplastic-development-increases-withnewapplications.html.

[5] J. Dai, K. Gliniewicz, M.L. Settles, E.R. Coats, A.G. McDonald, Influence of organic loading rate and solid retention time on polyhydroxybutyrate production from hybrid poplar hydrolysates using mixed microbial cultures, Bioresource Technol, 175 (2015) 23-33.

[6] E.R. Coats, F.J. Loge, W.A. Smith, D.N. Thompson, M.P. Wolcott, Functional stability of a mixed microbial consortium producing PHA from waste carbon sources, Appl Biochem Biotechnol, 136-140 (2007) 909-925.

[7] L. Wei, N.M. Guho, E.R. Coats, A.G. McDonald, Characterization of poly(3hydroxybutyrate-co-3-hydroxyvalerate) biosynthesized by mixed microbial consortia fed fermented dairy manure, J Appl Polym Sci, 131, Doi: 10.1002/app.40333 (2014).

[8] T.M. Keenan, J.P. Nakas, S.W. Tanenbaum, Polyhydroxyalkanoate copolymers from forest biomass, J Ind Microbiol Biotechnol, 33 (2006) 616-626. 
[9] B. Laycock, P. Halley, S. Pratt, A. Werker, P. Lant, The chemomechanical properties of microbial polyhydroxyalkanoates, Prog Polym Sci, 38 (2013) 536-583.

[10] B. Becker, M.P. Lechevalier, H.A. Lechevalier., Chemical composition of cell-wall preparations from strains of various form-genera of aerobic actinomycetes, Appl Environ Microbiol, 13 (1965) 236-243.

[11] A.H. Zacher, D.C. Elliott, M.V. Olarte, D.M. Santosa, F. Preto, K. Iisa, Pyrolysis of Woody Residue Feedstocks: Upgrading of Bio-oils from Mountain-Pine-Beetle-Killed Trees and Hog Fuel, Energy Fuels, 28 (2014) 7510-7516.

[12] D. Carpenter, T.L. Westover, S. Czernik, W. Jablonski, Biomass feedstocks for renewable fuel production: a review of the impacts of feedstock and pretreatment on the yield and product distribution of fast pyrolysis bio-oils and vapors, Green Chem, 16 (2014) 384-406.

[13] C.A. Mullen, A.A. Boateng, Production and analysis of fast pyrolysis oils from proteinaceous biomass, BioEnergy Res, 4 (2011) 303-311.

[14] J. Yanik, R. Stahl, N. Troeger, A. Sinag, Pyrolysis of algal biomass, J Anal Appl Pyrolysis, 103 (2013) 134-141.

[15] M. Otero, M.E. Sánchez, X. Gómez, Co-firing of coal and manure biomass: A TG-MS approach, Bioresource Technol, 102 (2011) 8304-8309.

[16] M. Fernandez-Lopez, M. Puig-Gamero, D. Lopez-Gonzalez, A. Avalos-Ramirez, J. Valverde, L. Sanchez-Silva, Life cycle assessment of swine and dairy manure: Pyrolysis and combustion processes, Bioresource Technol, 182 (2015) 184-192.

[17] S. Liang, Y. Han, L. Wei, A.G. McDonald, Production and characterization of bio-oil and bio-char from pyrolysis of potato peel wastes, Biomass Convers Biorefin DOI: 101007/s13399014-0130-x (2014).

[18] A.G. Barneto, J.A. Carmona, J.E.M. Alfonso, J.D. Blanco, Kinetic models based in biomass components for the combustion and pyrolysis of sewage sludge and its compost, J Anal Appl Pyrolysis, 86 (2009) 108-114.

[19] X. Chen, S. Jeyaseelan, Study of sewage sludge pyrolysis mechanism and mathematical modeling. Journal of environmental engineering, J Environ Eng, 127 (2001) 585-593.

[20] I. Fonts, M. Azuara, G. Gea, M.B. Murillo, Study of the pyrolysis liquids obtained from different sewage sludge, J Anal Appl Pyrolysis, 85 (2009) 184-191.

[21] E. Pokorna, N. Postelmans, P. Jenicek, S. Schreurs, R. Carleer, J. Yperman, Study of biooils and solids from flash pyrolysis of sewage sludges, Fuel, 88 (2009) 1344-1350.

[22] M.E. Sánchez, J.A. Menéndez, A. Domínguez, J.J. Pis, O. Martínez, L.F. Calvo, et al., Effect of pyrolysis temperature on the composition of the oils obtained from sewage sludge, Biomass Bioenerg, 33 (2009) 933-940. 
[23] L. Shen, D.-K. Zhang, An experimental study of oil recovery from sewage sludge by lowtemperature pyrolysis in a fluidised-bed, Fuel, 82 (2003) 465-472.

[24] Z.T. Dobroth, S. Hu, E.R. Coats, A.G. McDonald, Polyhydroxybutyrate synthesis on biodiesel wastewater using mixed microbial consortia, Bioresource Technol, 102 (2011) 33523359.

[25] N.B. Osman, A.G. McDonald, M.-P.G. Laborie, Analysis of DCM extractable components from hot-pressed hybrid poplar, Holzforschung, 66 (2012) 927-934.

[26] M. Chakraborty, A.G. McDonald, C. Nindo, S. Chen, An a-glucan isolated as a co-product of biofuel by hydrothermal liquefaction of Chlorella sorokiniana biomass, Algal Res, 2 (2013) 230-236.

[27] M.L. Passero, B. Cragin, A.R. Hall, N. Staley, E.R. Coats, A.G. McDonald, et al., Ultraviolet radiation pre-treatment modifies dairy wastewater, improving its utility as a medium for algal cultivation, Algal Res, 6 (2014) 98-110.

[28] S. Liang, A.G. McDonald, Chemical and thermal characterization of potato peel waste and its fermentation residue as potential resources for biofuel and bioproducts production, J Agric Food Chem, 62 (2014) 8421-8429.

[29] A.G. McDonald, M. Fernandez, B. Kreber, F. Laytner, The chemical nature of kiln brown stain in radiata pine, Holzforschung, 54 (2000) 12-22.

[30] F. Stoeckli, A. Guillot, A.M. Slasli, D. Hugi-Cleary, The comparison of experimental and calculated pore size distributions of activated carbons, Carbon, 40 (2002) 383-388.

[31] P. Sannigrahi, A.J. Ragauskas, G.A. Tuskan, Poplar as a feedstock for biofuels: A review of compositional characteristics, Biofuels, Bioprod Biorefin, 4 (2010) 209-226.

[32] W.-T. Chen, Y. Zhang, J. Zhang, L. Schideman, G. Yu, P. Zhang, et al., Co-liquefaction of swine manure and mixed-culture algal biomass from a wastewater treatment system to produce bio-crude oil, Appl Energ, 128 (2014) 209-216.

[33] M.F. Dignac, P. Ginestet, D. Rybacki, A. Bruchet, V. Urbain, P. Scribe, Fate of wastewater organic pollution during activated sludge treatment: nature of residual organic matter, Wat Res, 34 (2000) 4185-4194.

[34] L. Wei, S. Liang, A.G. McDonald, Thermophysical properties and biodegradation behavior of green composites made from polyhydroxybutyrate and potato peel waste fermentation residue, Ind Crop Prod, 69 (2015) 91-103.

[35] L. Wei, A.G. McDonald, C. Freitag, J.J. Morrell, Effects of wood fiber esterification on properties, weatherability and biodurability of wood plastic composites, Polym Degrad Stabil, 98 (2013) 1348-1361. 
[36] O.A. Lasode, A.O. Balogun, A.G. McDonald, Torrefaction of some nigerian lignocellulosic resources and decomposition kinetics, J Anal Appl Pyrolysis, 109 (2014) 47-55.

[37] S.S. Toor, L. Rosendahl, A. Rudolf, Hydrothermal liquefaction of biomass: A review of subcritical water technologies, Energy, 36 (2011) 2328-2342.

[38] L.M.L. Laurens, T.A. Dempster, H.D.T. Jones, E.J. Wolfrum, S. Van Wychen, J.S.P. McAllister, et al., Algal biomass constituent analysis: method uncertainties and investigation of the underlying measuring chemistries, Anal Chem, 84 (2012) 1879-1887.

[39] D. Klingler, J. Berg, H. Vogel, Hydrothermal reactions of alanine and glycine in sub- and supercritical water, J Supercrit Fluids, 43 (2007) 112-119.

[40] M.R. Pelaez-Samaniego, V. Yadama, M. Garcia-Perez, E. Lowell, A.G. McDonald, Effect of temperature during wood torrefaction on the formation of lignin liquid intermediates, $\mathrm{J}$ Anal Appl Pyrolysis, 109 (2014) 222-233.

[41] D. Fabbri, A. Adamiano, G. Falini, R. De Marco, I. Mancini, Analytical pyrolysis of dipeptides containing proline and amino acids with polar side chains. Novel 2,5-diketopiperazine markers in the pyrolysates of proteins, J Anal Appl Pyrolysis, 95 (2012) 145-155.

[42] J.-P. Cao, X.-Y. Zhao, K. Morishita, X.-Y. Wei, T. Takarada, Fractionation and identification of organic nitrogen species from bio-oil produced by fast pyrolysis of sewage sludge, Bioresource Technol, 101 (2010) 7648-7652.

[43] N. Gallois, J. Templier, S. Derenne, Pyrolysis-gas chromatography-mass spectrometry of the 20 protein amino acids in the presence of TMAH, J Appl Anal Pyrolysis, 80 (2007) 216-230.

[44] M. Fukushima, K. Furubayashi, N. Fujisawa, M. Takeuchi, T. Komai, K. Otsuka, et al., Characterization of humic acids in sediments from dam reservoirs by pyrolysis-gas chromatography/mass spectrometry using tetramethylammonium hydroxide: Influence of the structural features of humic acids on iron(II) binding capacity, J Appl Anal Pyrolysis, 91 (2011) 323-331.

[45] P.F. Britt, A.C. Buchanan, C.V. Owens, J. Todd Skeen, Does glucose enhance the formation of nitrogen containing polycyclic aromatic compounds and polycyclic aromatic hydrocarbons in the pyrolysis of proline?, Fuel, 83 (2004) 1417-1432.

[46] T.O. Munson, D.D. Fetterolf, Evidence for the formation of 2,4-imidazolidinediones and pyrrolidino[1,2a]-3,6-piperazinediones in human hair pyrolyzate by pyrolysis-gas chromatography-mass spectrometry-mass spectrometry, J Anal Appl Pyrolysis, 11 (1987) 15-24.

[47] D.P. Cole, E.A. Smith, D. Dalluge, D.M. Wilson, E.A. Heaton, R.C. Brown, et al., Molecular characterization of nitrogen-containing species in switchgrass bio-oils at various harvest times, Fuel, 111 (2013) 718-726. 
[48] L. Wei, A.G. McDonald, N.M. Stark, Grafting of bacterial polyhydroxybutyrate (PHB) onto cellulose via in-situ reactive extrusion with dicumyl peroxide., Biomacromolecules, 16 (2015)

1040-1049.

[49] P.J. Mitchell, T.S.L. Dalley, R.J. Helleur, Preliminary laboratory production and characterization of biochars from lignocellulosic municipal waste, J Anal Appl Pyrolysis, 99 (2013) 71-78.

[50] X. Ma, F. Zhang, L. Wei, Effect of wood charcoal contents on the adsorption property, structure, and morphology of mesoporous activated carbon fibers derived from wood liquefaction process, J Mater Sci, 50 (2014) 1908-1914.

[51] J. Zhang, F. Lu, H. Zhang, L. Shao, D. Chen, P. He, Multiscale visualization of the structural and characteristic changes of sewage sludge biochar oriented towards potential agronomic and environmental implication, Sci Rep, 5 (2015) 9406, DOI: 9410.1038/srep09406.

[52] J. McDonald-Wharry, M. Manley-Harris, K. Pickering, Carbonisation of biomass-derived chars and the thermal reduction of a grapheme oxide sample studied using Raman spectroscopy, Carbon, 59 (2013) 383-405.

[53] L. Zhao, X. Cao, O. Masek, A.Z. (2013), Heterogeneity of biochar properties as a function of feedstock sources and production temperatures, J Hazard Mater, 256- 257 (2013) 1-9. 
Table 1. Characterization of RBB feedstock and biochar.

\begin{tabular}{|c|c|c|}
\hline \multirow[b]{2}{*}{ Analyses } & \multicolumn{2}{|c|}{$\%$ dry basis ${ }^{*}$} \\
\hline & Biomass & Biochar \\
\hline \multicolumn{3}{|l|}{ Proximate analysis } \\
\hline Ash & $21.4 \pm 0.5$ & $60.3 \pm 0.0$ \\
\hline VM & $65.5 \pm 0.3$ & $18.1 \pm 0.7$ \\
\hline $\mathrm{FC}$ & $13.1 \pm 0.3$ & $21.6 \pm 0.8$ \\
\hline \multicolumn{3}{|l|}{ Ultimate analysis } \\
\hline $\mathrm{C}$ & $36.1 \pm 0.1$ & $27.7 \pm 0.4$ \\
\hline $\mathrm{H}$ & $5.3 \pm 0.0$ & $1.2 \pm 0.0$ \\
\hline $\mathrm{N}$ & $5.6 \pm 0.0$ & $4.9 \pm 0.0$ \\
\hline $\mathrm{O}^{\S}$ & $31.6 \pm 0.1$ & $5.9 \pm 0.3$ \\
\hline $\mathrm{C} / \mathrm{H}$ atomic ratio & 0.58 & 1.92 \\
\hline $\mathrm{C} / \mathrm{N}$ atomic ratio & 7.52 & 6.60 \\
\hline $\mathrm{C} / \mathrm{O}$ atomic ratio & 1.52 & 6.26 \\
\hline Calorific value $\left(\mathrm{MJ} \mathrm{kg}^{-1}\right)$ & $16.1 \pm 0.5$ & $20.0 \pm 0.6$ \\
\hline \multicolumn{3}{|l|}{ Chemical compositional analysis } \\
\hline Lipid & $10.1 \pm 0.1$ & \\
\hline Carbohydrate & $20.9 \pm 0.2$ & \\
\hline Acid insoluble residue & $27.1 \pm 0.1$ & \\
\hline Crude protein $(\mathrm{N} \% \times 6.25)$ & $35.0 \pm 0.0$ & \\
\hline BA $(\%)$ & & $2.1 \pm 0.0$ \\
\hline \multicolumn{3}{|l|}{ Surface area $\left(\mathrm{m}^{2} \mathrm{~g}^{-1}\right)^{* *}$} \\
\hline $\mathrm{N}_{2}(\mathrm{BET})$ & & $7.7 \pm 0.3$ \\
\hline $\mathrm{CO}_{2}(\mathrm{DR})$ & & $102 \pm 2$ \\
\hline
\end{tabular}

Data are means of three replicates \pm standard deviations.

** Data are means of two replicates \pm standard error.

${ }^{\S} \mathrm{O}=100-(\mathrm{C}+\mathrm{H}+\mathrm{N}+$ ash $)$ 
Table 2. Amino acid composition of protein hydrolysis and free amino acid in RBB (\% relative abundance) determined by GCMS.

\begin{tabular}{llllll}
\hline Amino acid & $\begin{array}{l}\text { Retention time } \\
(\mathrm{min})\end{array}$ & $\mathrm{M}^{+}(\mathrm{m} / z)$ & Formula & $\begin{array}{l}\text { Amino acid composition } \\
\text { after hydrolysis }(\%)\end{array}$ & $\begin{array}{l}\text { Free amino acid } \\
(\%)\end{array}$ \\
\hline Alanine & 6.2 & 89 & $\mathrm{C}_{3} \mathrm{H}_{7} \mathrm{NO}_{2}$ & 4.2 & 13.5 \\
Glycine & 6.5 & 75 & $\mathrm{C}_{2} \mathrm{H}_{5} \mathrm{NO}_{2}$ & 2.6 & 3.9 \\
Valine & 8.7 & 117 & $\mathrm{C}_{5} \mathrm{H}_{11} \mathrm{NO}_{2}$ & 3.3 & 5.5 \\
Threonine & 9.1 & 119 & $\mathrm{C}_{4} \mathrm{H}_{9} \mathrm{NO}_{3}$ & 4.8 & 3.5 \\
Serine & 9.4 & 105 & $\mathrm{C}_{3} \mathrm{H}_{7} \mathrm{NO}_{3}$ & 5.1 & 4.5 \\
Leucine & 10.3 & 131 & $\mathrm{C}_{6} \mathrm{H}_{13} \mathrm{NO}_{2}$ & 6.7 & 7.8 \\
Iso-leucine & 10.6 & 131 & $\mathrm{C}_{6} \mathrm{H}_{13} \mathrm{NO}_{2}$ & 2.6 & 3.5 \\
Proline & 12.6 & 115 & $\mathrm{C}_{5} \mathrm{H}_{9} \mathrm{NO}_{2}$ & 7.1 & 7.0 \\
Hydroxyproline & 14.9 & 131 & $\mathrm{C}_{5} \mathrm{H}_{9} \mathrm{NO}_{3}$ & 0.8 & trace \\
Methionine & 15.9 & 149 & $\mathrm{C}_{5} \mathrm{H}_{11} \mathrm{NO}_{2} \mathrm{~S}$ & 0.3 & trace \\
Aspartic acid & 17.4 & 133 & $\mathrm{C}_{4} \mathrm{H}_{7} \mathrm{NO}_{4}$ & 13.3 & 10.3 \\
Phenylalanine & 18.4 & 165 & $\mathrm{C}_{9} \mathrm{H}_{11} \mathrm{NO}_{2}$ & 5.4 & 3.0 \\
Glutamic acid & 20.3 & 147 & $\mathrm{C}_{5} \mathrm{H}_{9} \mathrm{NO}_{4}$ & 24.5 & 26.4 \\
Lysine & 21.6 & 146 & $\mathrm{C}_{6} \mathrm{H}_{14} \mathrm{~N}_{2} \mathrm{O}_{2}$ & 11.7 & 4.9 \\
Tyrosine & 22.4 & 181 & $\mathrm{C}_{9} \mathrm{H}_{11} \mathrm{NO}_{3}$ & 7.3 & 6.2 \\
Arginine & 24.1 & 174 & $\mathrm{C}_{6} \mathrm{H}_{14} \mathrm{~N}_{4} \mathrm{O}_{2}$ & 0.3 & trace \\
\hline
\end{tabular}


Table 3. Compounds released by Py-GCMS of extractive free RBB.

\begin{tabular}{|c|c|c|c|c|c|}
\hline No. & $\mathrm{RT}(\min )^{\mathrm{a}}$ & Compound & $\mathbf{M}^{+}(\mathrm{m} / \mathrm{z})$ & Formula & Relative abundance $(\%)^{\mathrm{b}}$ \\
\hline 1 & 1.23 & Acetaldehyde & 44 & $\mathrm{C}_{2} \mathrm{H}_{4} \mathrm{O}$ & $9.13 \pm 0.00$ \\
\hline 2 & 1.37 & Acetamide & 59 & $\mathrm{C}_{2} \mathrm{H}_{5} \mathrm{NO}$ & $4.40 \pm 0.01$ \\
\hline 3 & 1.78 & Acetic acid & 60 & $\mathrm{C}_{2} \mathrm{H}_{4} \mathrm{O}_{2}$ & $9.80 \pm 0.00$ \\
\hline 4 & 2.06 & Pyrrole & 67 & $\mathrm{C}_{4} \mathrm{H}_{5} \mathrm{~N}$ & $0.35 \pm 0.01$ \\
\hline 5 & 2.15 & 2-methylcyclopentanol & 100 & $\mathrm{C}_{6} \mathrm{H}_{12} \mathrm{O}$ & $0.51 \pm 0.02$ \\
\hline 6 & 3.25 & Toluene & 92 & $\mathrm{C}_{7} \mathrm{H}_{8}$ & $0.46 \pm 0.05$ \\
\hline 7 & 3.95 & 3-methylpyrrole & 81 & $\mathrm{C}_{5} \mathrm{H}_{7} \mathrm{~N}$ & $3.30 \pm 0.03$ \\
\hline 8 & 4.42 & 1,4-dimethyl-1H-pyrazole & 96 & $\mathrm{C}_{5} \mathrm{H}_{8} \mathrm{~N}_{2}$ & $2.44 \pm 0.01$ \\
\hline 9 & 5.14 & Butenoic acid & 86 & $\mathrm{C}_{4} \mathrm{H}_{6} \mathrm{O}_{2}$ & $1.05 \pm 0.10$ \\
\hline 10 & 5.64 & Benzonitrile & 103 & $\mathrm{C}_{7} \mathrm{H}_{5} \mathrm{~N}$ & $3.37 \pm 0.10$ \\
\hline 11 & 6.92 & 4-methyl-1,3-dioxolane & 88 & $\mathrm{C}_{4} \mathrm{H}_{8} \mathrm{O}_{2}$ & $2.35 \pm 0.05$ \\
\hline 12 & 7.16 & Pentenoic acid & 100 & $\mathrm{C}_{5} \mathrm{H}_{8} \mathrm{O}_{2}$ & $1.65 \pm 0.05$ \\
\hline 13 & 8.21 & Phenol & 94 & $\mathrm{C}_{6} \mathrm{H}_{6} \mathrm{O}$ & $1.74 \pm 0.00$ \\
\hline 14 & 9.21 & Diketopiperazine & 114 & $\mathrm{C}_{4} \mathrm{H}_{6} \mathrm{~N}_{2} \mathrm{O}_{2}$ & $2.05 \pm 0.00$ \\
\hline 15 & 9.78 & 2,6-dimethyl-1-piperidinamine & 128 & $\mathrm{C}_{7} \mathrm{H}_{16} \mathrm{~N}_{2}$ & $1.63 \pm 0.01$ \\
\hline 16 & 10.28 & 2-methylphenol & 108 & $\mathrm{C}_{7} \mathrm{H}_{8} \mathrm{O}$ & $0.86 \pm 0.00$ \\
\hline 17 & 10.93 & 3-methylphenol & 108 & $\mathrm{C}_{7} \mathrm{H}_{8} \mathrm{O}$ & $1.08 \pm 0.05$ \\
\hline 18 & 11.10 & Guaiacol & 124 & $\mathrm{C}_{7} \mathrm{H}_{8} \mathrm{O}_{2}$ & $1.58 \pm 0.10$ \\
\hline 19 & 13.25 & 1,4:3,6-dianhydro-hexopyranose & 144 & $\mathrm{C}_{6} \mathrm{H}_{8} \mathrm{O}_{4}$ & $3.26 \pm 0.13$ \\
\hline 20 & 13.87 & Propionic acid, pentyl ester & 144 & $\mathrm{C}_{8} \mathrm{H}_{16} \mathrm{O}_{2}$ & $2.59 \pm 0.10$ \\
\hline 21 & 14.01 & Methyl guaiacol & 138 & $\mathrm{C}_{8} \mathrm{H}_{10} \mathrm{O}_{2}$ & $3.12 \pm 0.00$ \\
\hline 22 & 15.01 & 3,5-diethylpyridin-4-amine & 150 & $\mathrm{C}_{9} \mathrm{H}_{14} \mathrm{~N}_{2}$ & $2.59 \pm 0.05$ \\
\hline 23 & 16.34 & 4-ethyl-guaiacol & 152 & $\mathrm{C}_{9} \mathrm{H}_{12} \mathrm{O}_{2}$ & $2.40 \pm 0.07$ \\
\hline 24 & 16.87 & Indole & 117 & $\mathrm{C}_{8} \mathrm{H}_{7} \mathrm{~N}$ & $2.18 \pm 0.07$ \\
\hline 25 & 17.30 & 4-vinyl guaiacol & 150 & $\mathrm{C}_{9} \mathrm{H}_{10} \mathrm{O}_{2}$ & $2.26 \pm 0.07$ \\
\hline 26 & 18.33 & Syringol & 154 & $\mathrm{C}_{8} \mathrm{H}_{10 \mathrm{O}_{3}}$ & $4.12 \pm 0.07$ \\
\hline 27 & 20.77 & Methyoxylmethyl-guaiacol & 168 & $\mathrm{C}_{9} \mathrm{H}_{12} \mathrm{O}_{3}$ & $3.32 \pm 0.03$ \\
\hline 28 & 22.07 & Undecenoic acid & 184 & $\mathrm{C}_{11} \mathrm{H}_{20} \mathrm{O}_{2}$ & $5.04 \pm 0.03$ \\
\hline 29 & 23.55 & Propioguaiacone & 180 & $\mathrm{C}_{10} \mathrm{H}_{12} \mathrm{O}_{3}$ & $2.82 \pm 0.07$ \\
\hline 30 & 26.59 & OHDPPD $^{c}$ & 194 & $\mathrm{C}_{10} \mathrm{H}_{14} \mathrm{~N}_{2} \mathrm{O}_{2}$ & $3.63 \pm 0.02$ \\
\hline 31 & 29.23 & Hexadecenoic acid & 254 & $\mathrm{C}_{16} \mathrm{H}_{30} \mathrm{O}_{2}$ & $4.44 \pm 0.07$ \\
\hline 32 & 43.94 & Docosenamide & 337 & $\mathrm{C}_{22} \mathrm{H}_{43} \mathrm{NO}$ & $10.86 \pm 0.01$ \\
\hline
\end{tabular}

${ }^{\mathrm{a}}$ RT: Retention time; $;{ }^{\mathrm{b}}$ relative abundance (\%) in the water dispersible fraction; ${ }^{\mathrm{c}}$ OHDPPD: octahydrodipyrrolo[1,2-a:1', 2'-d]pyrazine-5,10-dione. 
Table 4. GCMS and HPLC analyses results of ES and AQ fractions of pyrolyzed RBB, respectively.

\begin{tabular}{|c|c|c|c|c|c|}
\hline No. & $\mathrm{RT}(\min )^{\mathrm{a}}$ & Compound & $\begin{array}{l}\mathrm{M}^{+} \\
(\mathrm{m} / \mathrm{z})\end{array}$ & Formula & $\begin{array}{l}\text { Concentration } \\
(\% \text { WD })^{\mathrm{b}}\end{array}$ \\
\hline \multicolumn{6}{|l|}{ GCMS } \\
\hline 1 & 7.60 & 3-methyl-2-pentanone & 100 & $\mathrm{C}_{6} \mathrm{H}_{12} \mathrm{O}$ & $3.15 \pm 0.06$ \\
\hline 2 & 8.81 & Phenol & 94 & $\mathrm{C}_{6} \mathrm{H}_{6} \mathrm{O}$ & $9.22 \pm 0.56$ \\
\hline 3 & 10.13 & 3-methyl-1,2-cyclopentanedione & 112 & $\mathrm{C}_{6} \mathrm{H}_{8} \mathrm{O}_{2}$ & $0.91 \pm 0.00$ \\
\hline 4 & 10.45 & 2,3-dimethyl-2-cyclopentanedione & 110 & $\mathrm{C}_{7} \mathrm{H}_{10} \mathrm{O}$ & $0.83 \pm 0.06$ \\
\hline 5 & 10.92 & 2-Methylphenol & 108 & $\mathrm{C}_{7} \mathrm{H}_{8} \mathrm{O}$ & $0.68 \pm 0.07$ \\
\hline 6 & 11.55 & 3-Methylphenol & 108 & $\mathrm{C}_{7} \mathrm{H}_{8} \mathrm{O}$ & $2.22 \pm 0.04$ \\
\hline 7 & 11.85 & Guaiacol & 124 & $\mathrm{C}_{7} \mathrm{H}_{8} \mathrm{O}_{2}$ & $1.39 \pm 0.15$ \\
\hline 8 & 12.06 & 5-methyl-2,4-imidazolidinedione & 114 & $\mathrm{C}_{4} \mathrm{H}_{4} \mathrm{~N}_{2} \mathrm{O}_{2}$ & $5.08 \pm 0.00$ \\
\hline 9 & 12.62 & $\mathrm{~N}$-(2-Propenyl)-N-(2-Propynyl)-N-ethylamine & 123 & $\mathrm{C}_{8} \mathrm{H}_{13} \mathrm{~N}$ & $2.93 \pm 0.06$ \\
\hline 10 & 13.47 & 1,2.5-Trimethylpyrrole & 109 & $\mathrm{C}_{7} \mathrm{H}_{11} \mathrm{~N}$ & $5.74 \pm 0.52$ \\
\hline 11 & 14.24 & 3-ethyl-2,4-dimethyl-pyrrole & 123 & $\mathrm{C}_{8} \mathrm{H}_{13} \mathrm{~N}$ & $2.42 \pm 0.08$ \\
\hline 12 & 14.79 & Methyl-guaiacol & 138 & $\mathrm{C}_{8} \mathrm{H}_{10} \mathrm{O}_{2}$ & $1.30 \pm 0.17$ \\
\hline 13 & 15.35 & 2-(2-propynyloxy)cyclohexanol & 154 & $\mathrm{C}_{9} \mathrm{H}_{14} \mathrm{O}_{2}$ & $0.73 \pm 0.01$ \\
\hline 14 & 15.62 & 2-methyl-1-vinylimidazole & 108 & $\mathrm{C}_{6} \mathrm{H}_{8} \mathrm{~N}_{2}$ & $1.57 \pm 0.09$ \\
\hline 15 & 16.01 & Histidine & 155 & $\mathrm{C}_{6} \mathrm{H}_{9} \mathrm{~N}_{3} \mathrm{O}_{2}$ & $0.37 \pm 0.08$ \\
\hline 16 & 16.20 & 2-phenyl-4-pentenal & 160 & $\mathrm{C}_{11} \mathrm{H}_{12} \mathrm{O}$ & $0.21 \pm 0.00$ \\
\hline 17 & 16.74 & Histamine-2-carboxylic acid & 155 & $\mathrm{C}_{6} \mathrm{H}_{9} \mathrm{~N}_{3} \mathrm{O}_{2}$ & $0.76 \pm 0.21$ \\
\hline 18 & 17.02 & 5H-Pyrrolo-(3,2-d)pyrimidin-4-amine & 134 & $\mathrm{C}_{6} \mathrm{H}_{6} \mathrm{~N}_{4}$ & $1.50 \pm 0.04$ \\
\hline 19 & 17.42 & Indole & 117 & $\mathrm{C}_{8} \mathrm{H}_{7} \mathrm{~N}$ & $3.91 \pm 0.10$ \\
\hline 20 & 17.87 & $\mathrm{~N}, 2,4,6$-tetramethyl-bezenamine & 149 & $\mathrm{C}_{10} \mathrm{H}_{15} \mathrm{~N}$ & $3.06 \pm 0.09$ \\
\hline 21 & 19.27 & Syringol & 154 & $\mathrm{C}_{8} \mathrm{H}_{13} \mathrm{O}_{3}$ & $0.88 \pm 0.06$ \\
\hline 22 & 19.68 & Eugenol & 164 & $\mathrm{C}_{10} \mathrm{H}_{12} \mathrm{O}_{2}$ & $0.47 \pm 0.01$ \\
\hline 23 & 23.00 & Butylated hydroxytoluene & 220 & $\mathrm{C}_{15} \mathrm{H}_{24} \mathrm{O}$ & $2.55 \pm 0.21$ \\
\hline \multicolumn{6}{|l|}{ HPLC } \\
\hline 1 & 15.91 & Levoglucosan & 162 & $\mathrm{C}_{6} \mathrm{H}_{10} \mathrm{O}_{5}$ & $3.12 \pm 0.53$ \\
\hline 2 & 17.60 & Formic acid & 46 & $\mathrm{CH}_{2} \mathrm{O}_{2}$ & $1.90 \pm 0.36$ \\
\hline 3 & 21.03 & Acetic acid & 60 & $\mathrm{C}_{2} \mathrm{H}_{4} \mathrm{O}_{2}$ & $41.25 \pm 0.27$ \\
\hline 4 & 24.29 & Propanoic acid & 74 & $\mathrm{C}_{3} \mathrm{H}_{6} \mathrm{O}_{2}$ & $1.86 \pm 0.10$ \\
\hline
\end{tabular}

${ }^{a}$ RT: retention time. ${ }^{b}$ Concentration: $\%$ in the water dispersible (WD) fraction. The values were calculated from duplicates, while standard deviation was shown after \pm . 
Table 5. Boiling point distribution of pyrolysis bio-crude.

\begin{tabular}{lll}
\hline Temperature range $\left({ }^{\circ} \mathrm{C}\right)$ & Product distribution $(\%)$ & Compound \\
\hline $\begin{array}{l}\text { Pyrolysis bio-crude } \\
50-220\end{array}$ & 89.0 & $<\mathrm{C}_{12}$ \\
$220-440$ & 10.0 & $\mathrm{C}_{13}-\mathrm{C}_{30}$ \\
$440-500$ & 1.0 & $>\mathrm{C}_{30}$ \\
Wax standard & & \\
$50-210$ & 60.5 & $<\mathrm{C}_{12}$ \\
$210-270$ & 32.1 & $\mathrm{C}_{13}-\mathrm{C}_{16}$ \\
$270-450$ & 7.3 & $\mathrm{C}_{17}-\mathrm{C}_{30}$ \\
$450-550$ & 0.1 & $>\mathrm{C}_{30}$ \\
\hline
\end{tabular}


Table 6. FTIR spectral band assignments for residual bacterial biomass (RBB) and pyrolysis biochar samples.

\begin{tabular}{llc}
\hline \multirow{2}{*}{ Band assignment } & \multicolumn{2}{c}{ Band frequency $\left(\mathrm{cm}^{-1}\right)$} \\
\cline { 2 - 3 } & RBB & Biochar \\
\hline Bonded -O-H, -N-H stretching & 3380,3304 & 3338 \\
-O-H stretching & 2928 & 2928 (weak) \\
-C=O stretching & 1724 (weak) & \\
Amide I band & 1641 & 1586 \\
Aromatic C-C/C=C stretching & & \\
Amide II band & 1538 & \\
Deformation of -CH, -CH & \\
C-O stretching and $\mathrm{O}-\mathrm{H}$ bending & 1451,1416 & 1050 \\
Silicate; C-O stretching & 1232 & \\
\hline
\end{tabular}




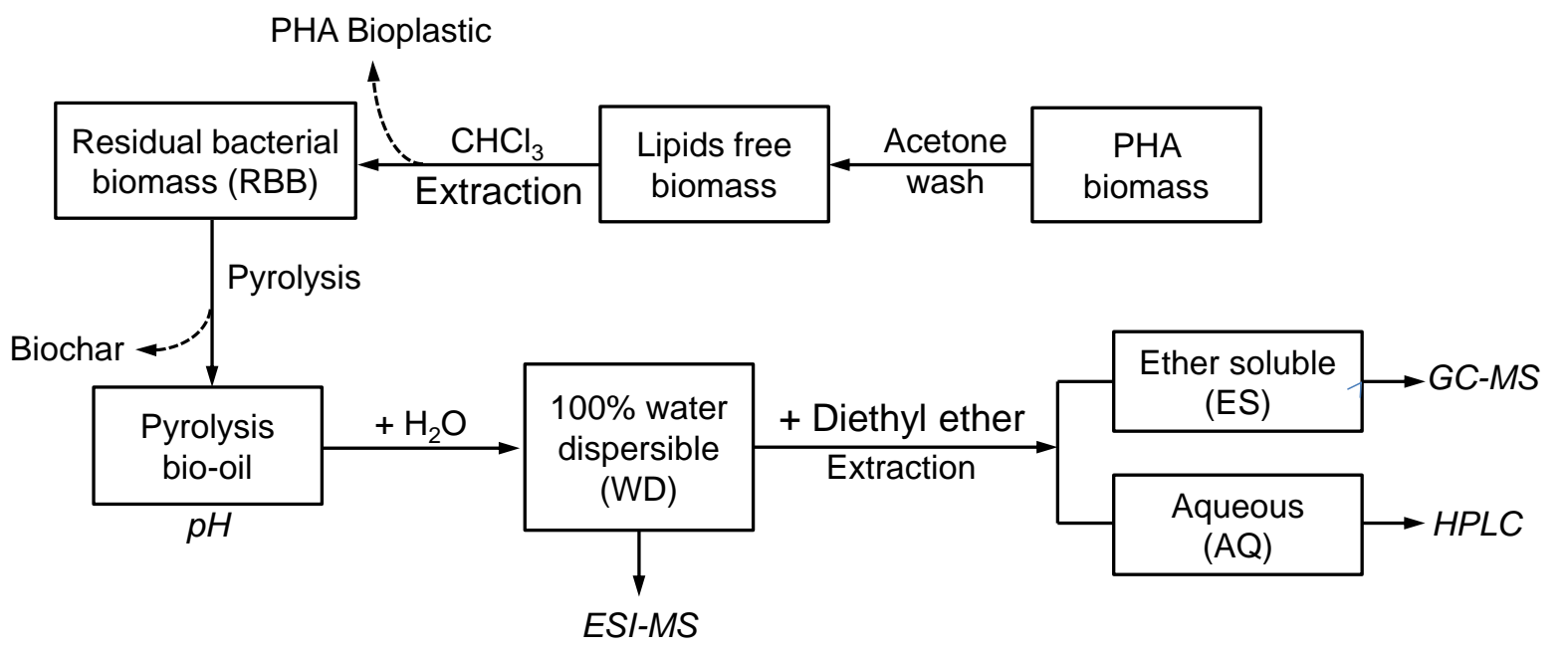

Fig. 1. Flow diagram of experiment steps performed, sample generation and analyses performed. 


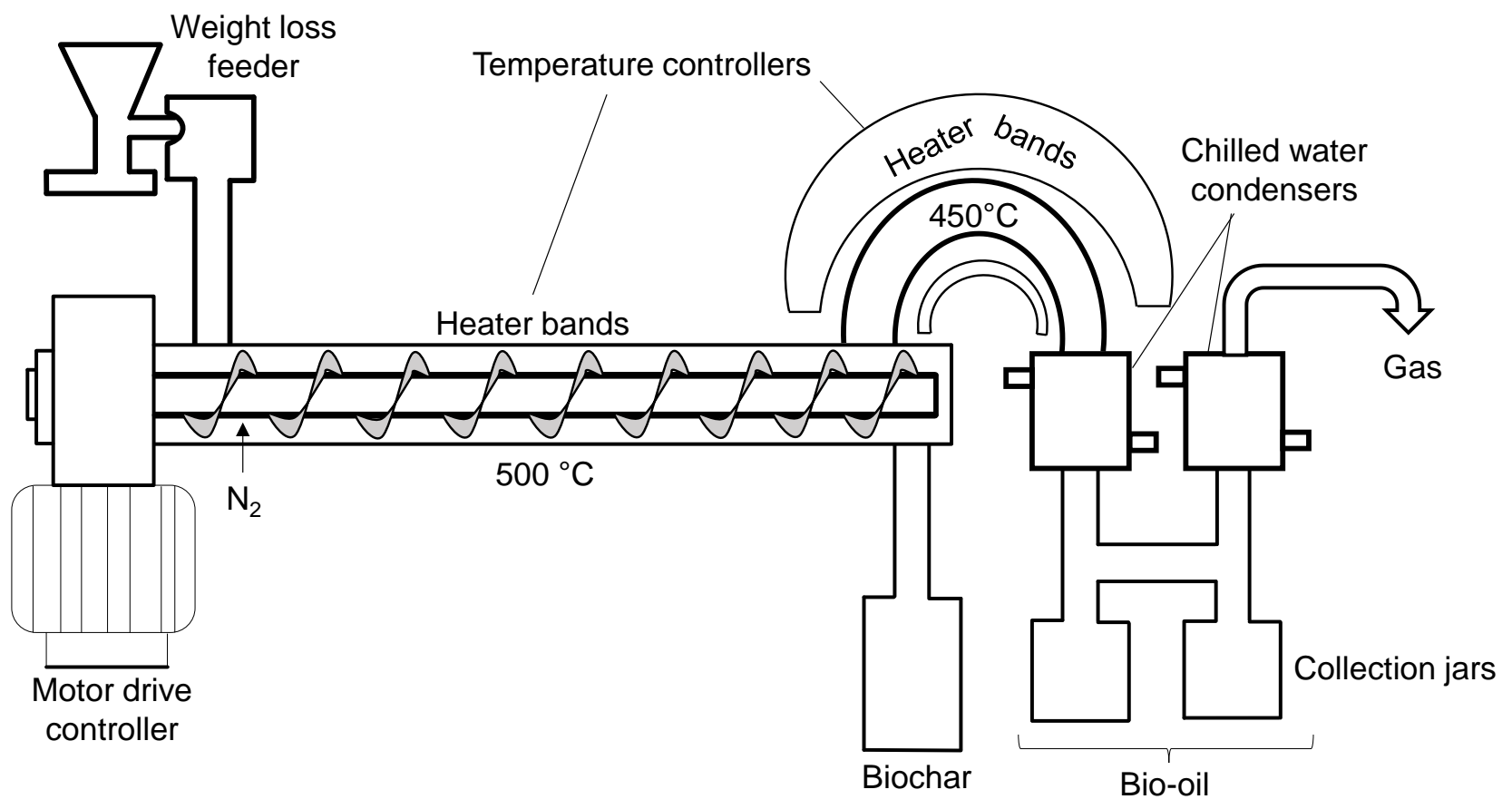

Fig. 2. A schematic diagram of the laboratory auger pyrolysis reactor apparatus. 


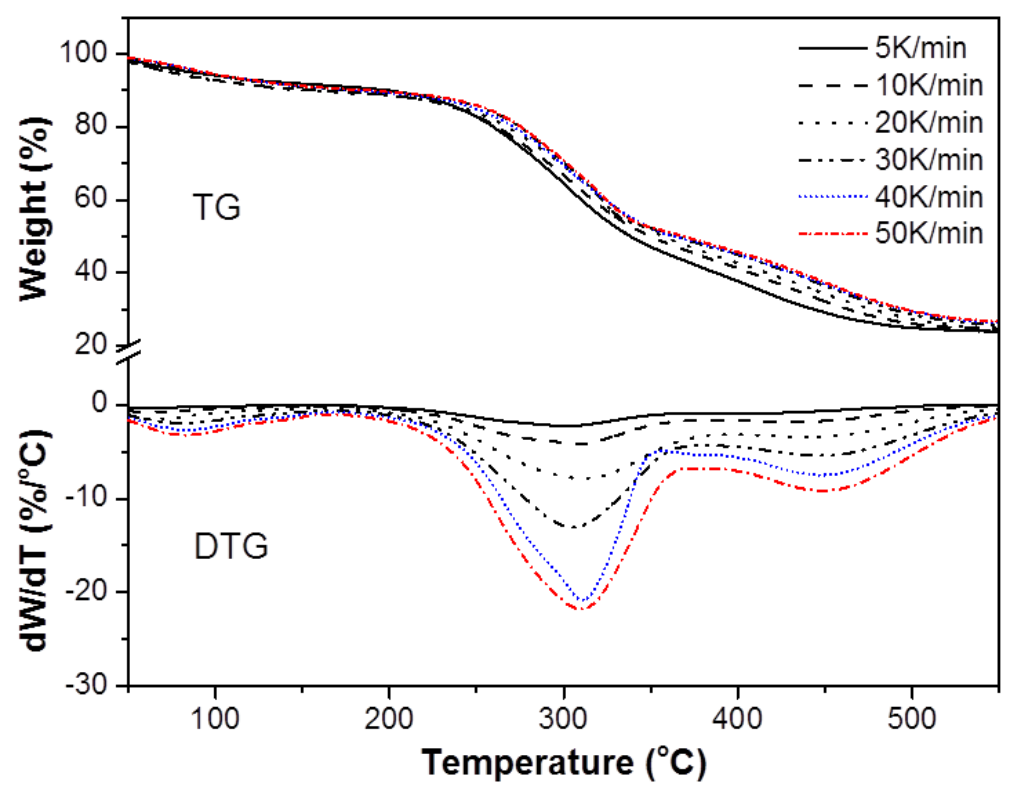

Fig. 3. TG and DTG thermograms of residual bacterial biomass (RBB) at different heating rates $\left(5-50 \mathrm{~K} \mathrm{~min}^{-1}\right)$. 

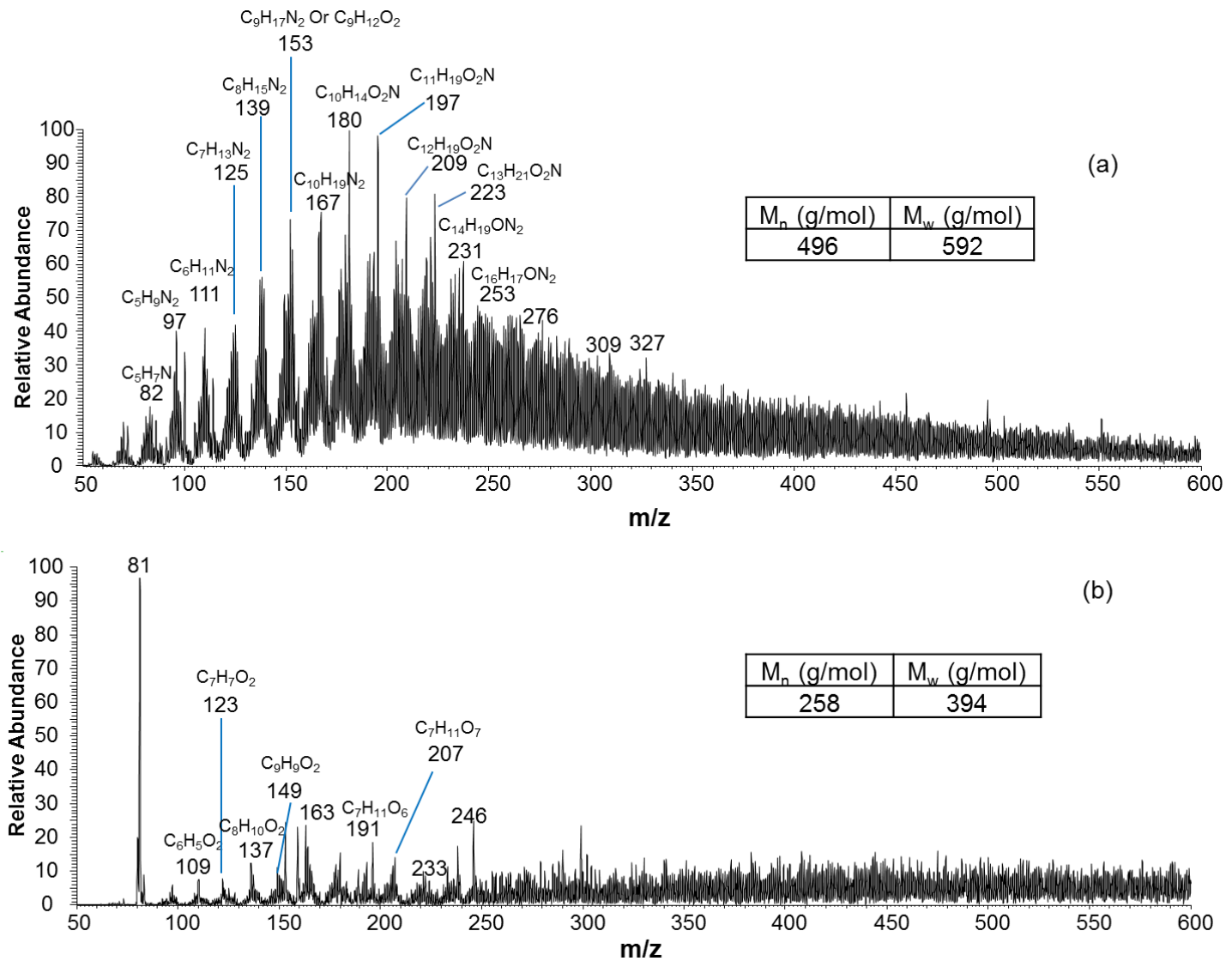

Fig. 4. (a) Positive and (b) negative ion ESI-MS of water dispersible (WD) bio-oil from pyrolysis of residual bacterial biomass (RBB). 


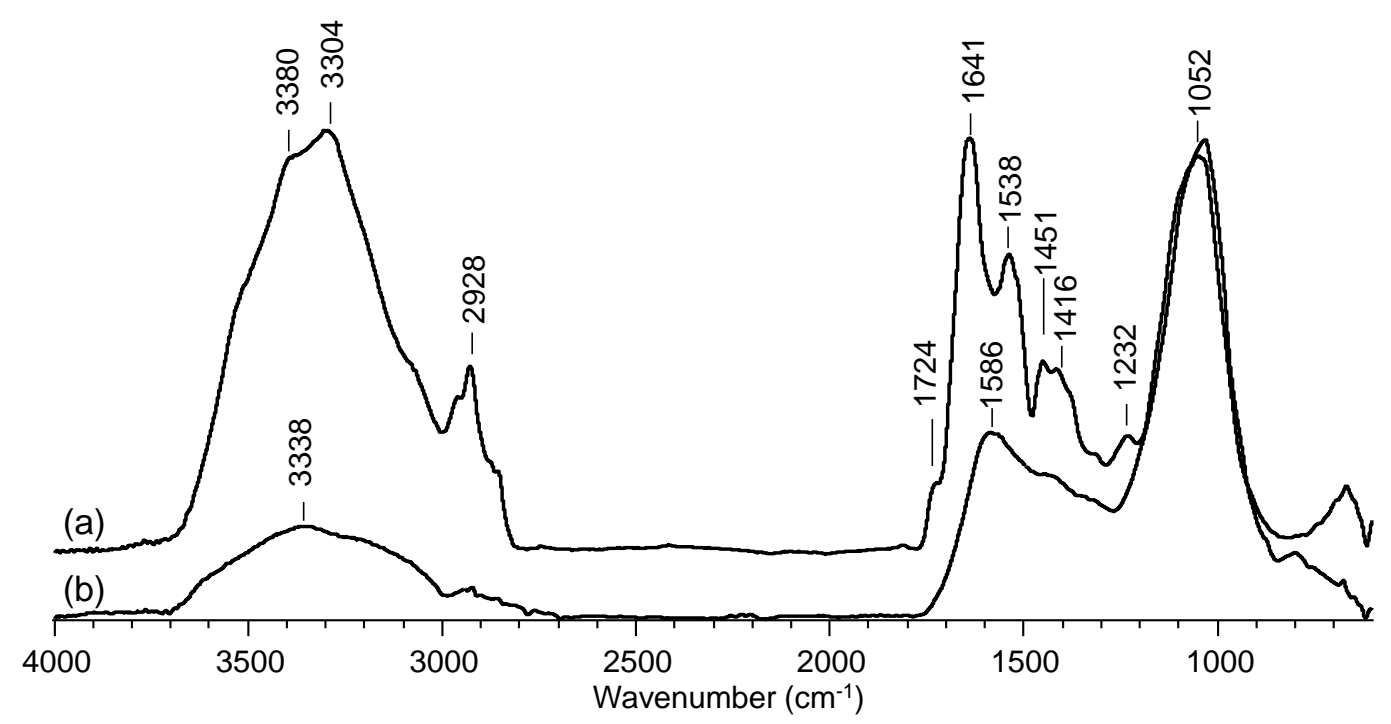

Fig. 5. FTIR spectra of (a) residual bacterial biomass (RBB) and (b) biochar. 


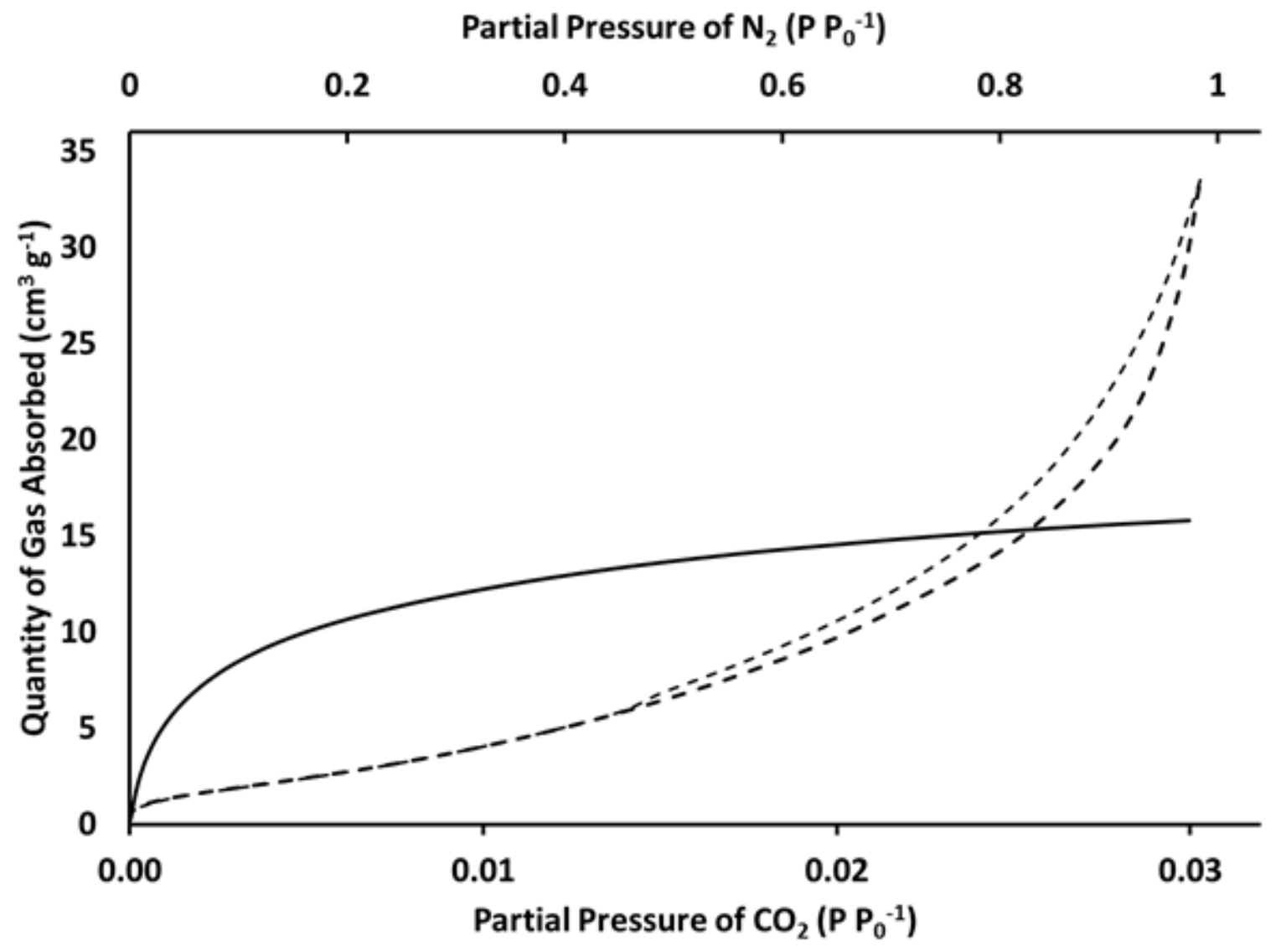

Fig. 6. Absorption isotherms for residual bacterial biomass (RBB) biochar. Solid line represents $\mathrm{CO}_{2}$ absorption while dashed line represents $\mathrm{N}_{2}$ absorption/desorption. 


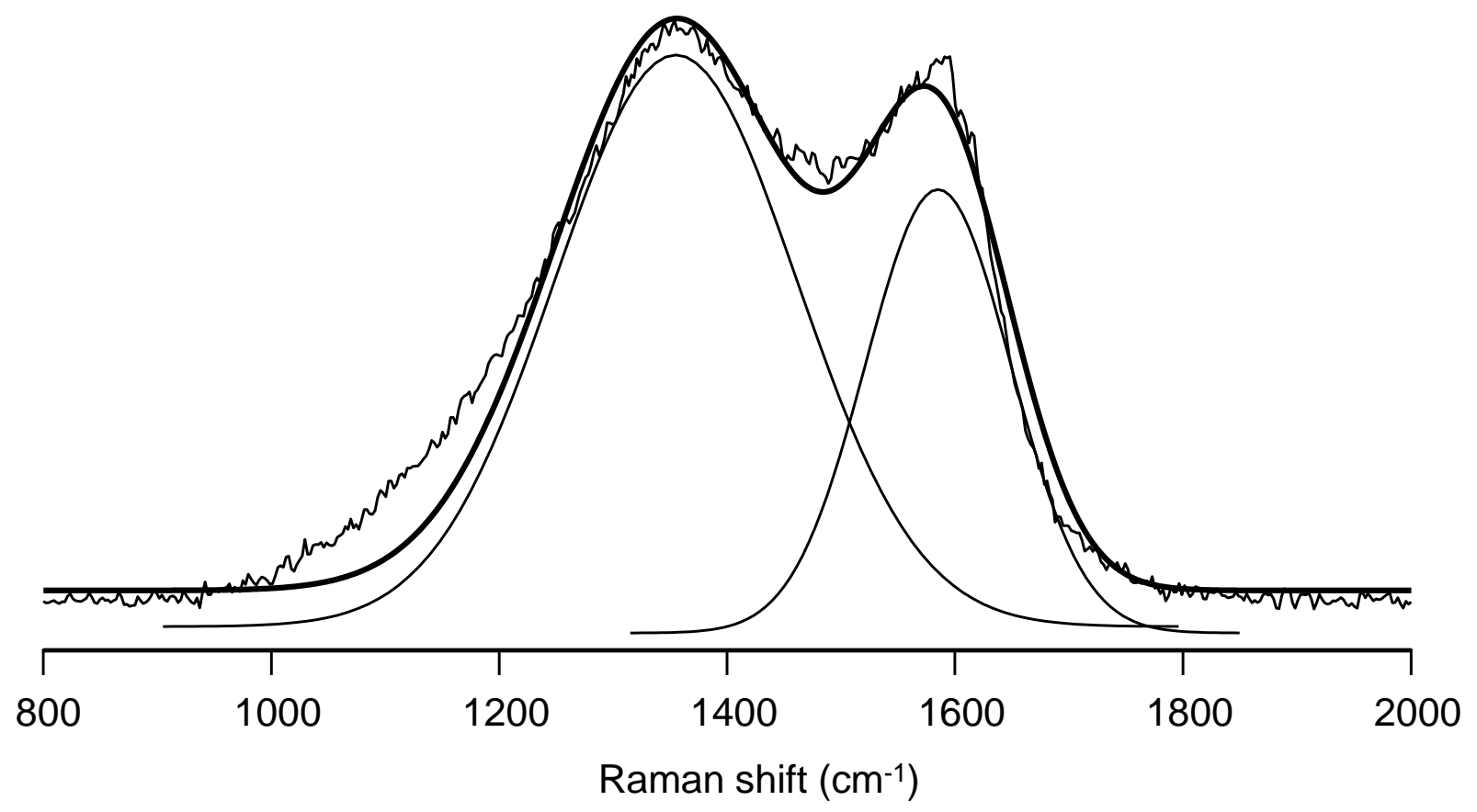

Fig. 7. Raman spectrum of residual bacterial biomass (RBB) biochar. 